\title{
Türkiye'de Yenilenebilir Kaynaklara Dayalı Elektrik Üretimini Etkileyen Faktörler: Rüzgar ve Güneş Enerjisi Örneğinde Kar Amacı Motivasyonuna göre Farklılaşan Engeller ve Destekler
}

\author{
Yelda Erden Topal $^{1 *}$, Betül Hande Gürsoy Haksevenler ${ }^{2}$, Erkan Erdil $^{1}$

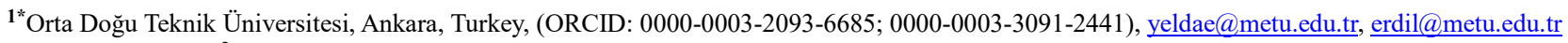 \\ ${ }^{2}$ Marmara Üniversitesi, İstanbul, Turkey, (ORCID: 0000-0003-3711-5058), hande.gursoy@marmara.edu.tr
}

(DOI:10.31590/ejosat.1045546)

\begin{abstract}
ATIF/REFERENCE: Erden Topal, Y., Gürsoy Haksevenler, B. H. \& Erdil, E. (2021). Türkiye'de Yenilenebilir Kaynaklara Dayalı Elektrik Üretimini Etkileyen Faktörler: Rüzgar ve Güneş Enerjisi Örneğinde Kar Amacı Motivasyonuna göre Farklılaşan Engeller ve Destekler. European Journal of Science and Technology, (32), 901-916.

$\ddot{O} \mathbf{z}$

Enerji talebinin hızlı artışı ve enerji kaynaklarının bu artışı karşılamakta göreceli olarak yetersiz kalması, enerjinin sürdürülebilir olarak üretilmesini gündeme taşımaktadır. Ülkemizde enerji kaynaklarının büyük bir kısmının ithal ediliyor olması, yerli ve yenilenebilir enerji kaynaklarının elektrik üretiminde kullanılmasının yaygınlaştırılmasını daha da önemli hale getirmektedir. Gelişmekte olan teknolojiler olarak adlandırılan rüzgar ve güneş enerjisine dayalı elektrik üretim teknolojileri, (hidroelektrik üretim teknolojileri gibi) diğer yenilenebilir enerji türlerine nazaran daha az kullanılan teknolojilerdir. Bu sebeple, elektrik üretiminde bu kaynakların kullanımının artması konusundaki engellerin ve desteklerin belirlenmesi ve tahlil edilmesi büyük önem taşımaktadır. Bu kapsamda, Türkiye'de yenilenebilir enerji kaynaklarına dayalı elektrik üretimi ile doğrudan veya dolaylı olarak bağlantılı olan aktörlerden 57 temsilci ile açık uçlu sorulardan oluşan yarı yapılandırılmış mülakatlar gerçekleştirilmiş̧ir. Çalışmada açık kodlama yöntemiyle 40 adet destekleyici faktör, 40 adet engelleyici faktör belirlenmiştir. Bu faktörler, ekonomik, fiziksel, kurumsal, psikolojik, teknolojik, siyasi ve yönetimsel olmak üzere yedi ayrı başlık altında gruplanmıştı. Elde edilen bulgularda, ekonomik, kurumsal, yönetimsel ve siyasi faktörlerin daha çok ön plana çıktığı gözlenmiştir. Ülkemizde doğrudan kar amacı güden özel sektör ve kar amacı gütmeyen diğer sektörlerdeki aktörlerin gözünden derlenen bu faktörler analiz edildiğinde, kar amacı güden sektörlerdeki aktörler için daha çok siyasi faktörlerin, yönetimsel faktörlerin ve kurumsal faktörlerin belirleyici olduğu; kar amacı gütmeyen aktörler için ise daha çok ekonomik faktörlerin belirleyici olduğu görülmüsştür. Siyasi faktörler ve yönetimsel faktörler içinde en çok öne çıkan faktörler destek ve teşvikler, mevcut alt yapı ve bürokratik uygulamalar ile ilgili olurken, Kurumsal faktörler içinde iş birliği ve koordinasyon mekanizmaları belirleyici unsur olmuştur. Ekonomik faktörler en çok maliyet ve yatırım kaynaklı mekanizmalar, destekler ve engeller bağlamında değerlendirilmiştir.
\end{abstract}

Anahtar Kelimeler: Yenilenebilir enerji teknolojileri, engelleyen faktörler, destekleyen faktörler, Türkiye, kar motivasyonu

\section{The Factors Effecting Renewable Energy Generation in Turkey: Different Inducement and Blocking Mechanisms depending on Profit Motivation in Solar and Wind Energy}

\begin{abstract}
The rapid increase in energy demand and the relative inadequacy of energy resources to meet this increase brings sustainable energy production to the agenda. Most energy resources are imported, making it even more critical to expand domestic and renewable energy resources in electricity generation. Electricity generation technologies based on wind and solar energy, called emerging technologies, are less used than other types of renewable energy (such as hydroelectricity). For this reason, it is of great importance to identify and analyze the inducement and blocking factors for motivating the use of these resources in electricity generation. In this context, semistructured interviews were conducted with 57 representatives from actors directly or indirectly related to renewable electricity generation in Turkey. In the study, 40 inducement factors and 40 blocking factors were determined by the open coding method. These factors are grouped under seven different headings: Economic, physical, institutional, psychological, technological, political and organizational. In the findings, it was observed that economic, institutional, political and organizational factors came to the fore. When the factors that prevent and support the diffusion of renewable energy technologies, compiled from the eyes of the relevant actors in the private and non-private sectors, are analyzed, it is determined that political factor, organizational factors and institutional factors are the main determinants for inducement and blocking mechanisms in the private sector. For the non-private sector, it was seen that primarily
\end{abstract}

*Sorumlu Yazar: yeldae@metu.edu.tr 
economic factors were the main determinants. Among the economic factors, the most prominent ones are cost-based and investmentbased mechanisms. Cooperation and coordination mechanisms are the prominent institutional factors, and among the political and organizational factors, supports and incentives, existing infrastructure, and bureaucratic practices come to the fore.

Keywords: Renewable Energy Technologies, Inducement Factors, Blocking Factors, Turkey, profit motive

\section{Giriş}

Günümüzde ülkelerin karşı karşıya kaldığı en önemli problemlerin başında, enerjinin güvenliği ve sürdürülebilirliği yer almaktadır. Sanayileşme ve çoğalan nüfusla, enerji ihtiyacı artmakta; bu ihtiyaç ise mevcut sınırlı kaynaklarla giderilememektedir. Dünya genelinde enerji ihtiyacının \%8090'nı fosil temelli yakıtlardan elde edilmektedir. Ancak bu kaynakların yakın gelecekte tükeniyor olması, çevre kirliliğine sebep olmaları ve iklim değişikliğine neden olan önemli etkenler arasında yer almaları; enerji tedarikinde ve temininde yeni alternatif yollar aranmasını gerektirmektedir. Bu alternatif enerji kaynakları arasında yer almakta olan yenilenebilir enerji, hem doğaya zarar vermemekte hem de fosil kaynaklı yakıtlara göre çok düşük maliyetlerde arz edilebilmektedir. Bunların dışında, yenilenebilir enerji kullanımı ile Türkiye gibi enerji konusunda önemli ölçüde dışa bağlı ülkelerin bağımlılığını asgari düzeye indirebilmektedir (Emeksiz ve Fındık, 2021; Kayar ve diğ., 2021).

TMOBB tarafindan hazırlanan “Türkiye'nin Enerji Görünümü” raporunda da belirtildiği üzere, ülkemiz enerji talebinin \%83,5'inin fosil yakıtlardan temin edilmesine karşın ülkemiz fosil kaynaklar açısından zengin bir coğrafyada yer almamaktadır. Mevcut enerji talebine göre ülkemizin enerjide dışa bağımlılığı \%70 olarak belirlenmiştir (Karagöl ve Kavaz, 2017). 2020 yılı verilerine göre Türkiye doğal gaz ihtiyacının \%99,1'ini, petrol ihtiyacının \%92,9'unu diş kaynaklardan karşılamaktadır (Türkiye Petrolleri, 2020). Bununla birlikte, 2020 yılında Karadeniz'de keşfedilen doğal gaz ile enerji bağımsızlığ 1 yolunda önemli bir adım atılmıştır. Ancak enerji alanında asıl bağımsızlığın, enerji üretiminde (kaynak ve üretim teknolojileri açısından) yerlilik oranını artırılması ve yerli yenilenebilir enerji kaynaklarına geçilmesiyle elde edileceği öngörülmektedir.

Türkiye yenilenebilir enerji kaynakları olan güneş, rüzgar, biyokütle ve hidroelektrik enerji açısından büyük bir potansiyele sahiptir. 2021 yılı itibarıyla devlet ve özel sektör tarafından yapılan yatırımlar sayesinde, ülkemizde mevcut elektrik enerjisi kurulu gücünün \%52'sini yenilenebilir kaynaklı santraller oluşturmaktadır (Türkiye Cumhuriyeti Dışişleri Bakanlığı, 2021). $\mathrm{Bu}$ rakamlarla ülkemiz yenilenebilir enerji kurulu gücünde Dünya'da 12., Avrupa'da ise 5. sıraya yükselmiştir. Türkiye'deki elektrik tesislerine kurulu güç olarak bakıldığında Mart 2021 verilerine göre doğalgaz ile çalışan santraller, mevcut kurulu gücün \%26'sı ile başı çekmektedir. Ardından kurulu gücün $\% 24$ 'ünü barajlar, \%10'unu linyit, \%9,6'sını rüzgar, \%9,2'sini ithal kömür, \%8,3'ü akarsular, \%7,2'si güneş oluşturmaktadır. Diğer kurulu güç kaynakları jeotermal, biyokütle, fuel oil, asfaltit kömür, motorin olarak sıralanmaktadır (Türkiye Elektrik İletim A.Ş., 2021). Ülkemizde elektrik üretiminde yenilenebilir enerji kaynaklarının kullanımı adına yapılan düzenlemeler içinde yer alan T.C. Enerji ve Tabii Kaynaklar Bakanlığı 2019-2023 Stratejik Planı'nda, 2023 yılında yerli ve yenilenebilir enerji kaynaklarına dayalı elektrik kurulu gücünün toplam kurulu güce oranının $\% 65$ değerine yükseltilmesi hedeflenmiştir (Enerji ve Tabii Kaynaklar Bakanlığı, 2019). Diğer taraftan, ülkemiz Paris İklim Anlaşmasından doğan yükümlülükleri gereği 2053 yılına "Sıfır Emisyon Hedefi"ni koymuştur. $\mathrm{Bu}$ durumda, yenilenebilir enerjinin kullanımı açısından hızla ivmelenen adımlar atılması beklenmektedir.

Yenilenebilir enerji kaynakları arasında yer alan rüzgar enerjisi açısından ülkemizin potansiyeli incelendiğinde yüksekliği $50 \mathrm{~m}$ ve üzerinde, rüzgar hızı $7,5 \mathrm{~m} / \mathrm{s}$ 'den daha fazla olan bölgeler üzerinden elektrik enerjisi üretimi potansiyeli yaklaşık 48 bin MW olarak hesaplanmaktadır (Bektaş, 2013). 2021 yılı başı itibarıyla ülkemizde 333 adet rüzgar enerjisi santrali olup, mevcut kurulu güç 9361 MW değerindedir (Türkiye Elektrik İletim A.Ş., 2021). Ülkemizdeki güneş enerjisi potansiyeli ile ilgili olarak Enerji ve Tabii Kaynaklar Bakanlığı tarafından hazırlamış olan Güneş Enerjisi Potansiyeli Atlası’na göre Türkiye genelinde ortalama günlük güneşlenme süresi 7,5 saat/gün ve ortalama toplam 1şınım şiddeti $4,18 \mathrm{kWh} / \mathrm{m} 2$-gün olarak hesaplanmıştır. Güneş enerjisinden esas olarak üretilen 1s1 enerjisi olup, ısıdan hem doğrudan faydalanılmakta hem de elektrik üretiminde kullanılabilmektedir (Enerji ve Tabii Kaynaklar Bakanlığı, 2021). Türkiye 2021 başı itibariyle 7779 adet güneş enerjisi santrali olup 6964 MW kurulu güce sahiptir (Türkiye Elektrik İletim A.Ş., 2021).

Bütün bu veriler 1şı̆̆ında ülkemizde yenilenebilir enerji kaynakların verimli bir şekilde kullanımına ilişkin mevcut gelişme hızının yeterli olmadığı ve bu durumun bazı hukuki ve ekonomik kısıtlardan kaynaklandığı gözlenmektedir. Diğer taraftan özellikle güneş enerjisi olmak üzere, yenilenebilir enerji kullanımı konusunda atılan adımların 2015 yılından sonra hız kazandığı göz önüne alındığında, gelinen noktanın umut verici olduğu düşünülmektedir. Ülkemizde özellikle rüzgâr ve güneş enerjisi kullanımına ilişskin hedeflere başarıyla ulaşılabilmesi için Türkiye'deki enerji üretim ve tüketimi değerlendirilirken elektrik kaleminin incelenmesi ve elektrik üretiminde rüzgâr ve güneş enerjisi kullanımının teşvik edilmesi, hızla artan enerji talebinin yerli kaynaklarla, temiz ve sürdürülebilir olarak karşılanması açısından oldukça anlamlıdır. Buradan hareketle, Türkiye'de elektrik üretiminde rüzgâr ve güneş enerjisinin kullanılmasının teşvik edilmesi ve yaygınlaşması konusundaki engellerin ve desteklerin belirlenmesi önerilmektedir.

Yaygın yazındaki çalışmalar, genellikle ülkelerin yenilenebilir kaynaklarından elektrik üretme potansiyelleri, sanayilerini geliştirme performansları ve ulaşılan olumlu/olumsuz sonuçların nedenleri üzerinde durmaktadır (Jacobsson ve Bergek, 2004; Jacobsson ve Lauber, 2006; Wüstenhagen ve Bilharz, 2006; Gan ve diğ., 2007; Marinova ve Balaguer, 2009; Dewald and Truffer, 2011; Wu ve Mathews, 2012; Weber ve Rohracher, 2012). Bu çalışmalar genelinde destekleyici faktörler arasında öne çıkanlar araştırma ve geliştirme politikalarında çeşitliliğin artırılması, sınai üretimde yenilenebilir kaynak kullanımının meşrulaştırılması, elektrik üreticilerinin güçlü yaygınlaştırma faaliyetleri, ilgili politikaların sarih ve tutarlı olması, politika araç ve amaçları arasında tamamlayıcılığın sağlanması, söz konusu enerji teknolojilerini de kapsayan sanayi ve üretim politikaları tasarlanması, ülkelerin stratejik önceliklerini belirleyerek enerji politikalarını şekillendirmeleri olarak özetlenebilecektir. Engeller arasında ise, sektördeki yerleşik ve yaygın teknolojilerin (doğrudan veya dolaylı) karşı lobi faaliyetleri, tedarikçi firmaların sektöre yeni giren firmalarla işbirliği bağlarını verimli olarak 
tahsis edememeleri, yenilenebilir enerji kullanımını teşvik eden sanayi politikalarının olmaması, araştırma geliştirme desteklerinin cesaret kırıcı olması, ülkenin politika tasarımı ve araç seçimi konusunda öngörülü ve net davranamaması vardır. Bundan hareketle, yenilenebilir enerji kaynaklarından elektrik üretim performansının; ülkelerin izledikleri politikalara, bu politikalarla sağladıkları teşvik mekanizmalarına ve bunların uygulama sonuçlarına referansla anlatılmakta olduğunu söylemek mümkündür. Örneğin Almanya ve İspanya'daki güneş enerjisi gelişimini inceleyen Dewald and Truffer (2011), iki ülkenin de yenilenebilir kaynaklara dayalı elektrik üretiminde temel destekleyici mekanizma olarak devlet teşvikini kullanmalarına rağmen İspanya'nın başarısız, Almanya'nın ise başarılı olduğu sonucuna ulaşmışlardır. $\mathrm{Bu}$ yüzden sadece politikalar tasarlamanın, yenilenebilir enerji teknolojilerinin yayılması açısından yeterli olmadığı söylenebilir. Politikaların, sistemin bütününde aksaklığa yol açan nokta belirlenerek, onun geliştirilmesi amacıyla tasarlanması gerekir. Weber ve Rohracher (2012)'in dediği gibi, teknoloji ve yenilik politikalarının temelinde, sistem yapısını güçlendiren ve zayıflatan faktörlerin ortaya koyulması ve sistem performansının bu faktörler vasitasıyla analiz edilmesi sonucunda, sistemin istenen yönde desteklenmesi için politikalar tasarlanması yatmaktadır.

$\mathrm{Bu}$ bağlamdan hareketle çalışmanın temel konusu yenilenebilir enerji teknolojilerinin yayılmasını engelleyen ve destekleyen faktörlerin belirlenmesidir. Çalışmada rüzgâr ve güneş enerjisi örneğinden yola çıkarak “Türkiye'de yenilenebilir enerji kaynaklarından elektrik üretiminin yayılmasında engelleyen ve destekleyen faktörler nelerdir?" sorusuna cevap aranmaktadır. $\mathrm{Bu}$ soruya yanıt aranırken, kar amacı motivasyonuna göre farklılaşan faktörler değerlendirilmiştir.

Çalışmanın temel çıkış noktası ve araştırma sorusunun tanımlandığı Giriş bölümünü takiben, Materyal ve Metod bölümünde çalışma kapsamında toplanan veri ve bu verinin analiz edilme yöntemleri tarif edilmiştir. Üçüncü bölüm olan Yazın Taramasında yenilenebilir enerji teknolojilerinin yayılmasını etkileyen faktörler literatürden örneklerle sıralanmış; Araştırma Sonuçları ve Tartışma başlıklı dördüncü bölümde ise, elde edilen veriler 1şı̆̆ında Türkiye'deki engelleyici ve destekleyici faktörler belirlemiştir. Çalışma, sonuçların tartışıldığı son bölüm ile tamamlanmıştır.

\section{Materyal ve Metot}

Çalışmamız, açık uçlu mülakat yöntemiyle toplanan verinin analizine dayanmaktadır. Mülakat çalışmasında cevap aranan temel araştırma sorusu “Türkiye'de yenilenebilir enerji kaynaklarına dayalı elektrik üretimi teknolojilerinin yayılmasını etkileyen faktörler nelerdir? sorusudur. Yanıt bulmak için, ilk aşamada, enerji sektöründeki mevcut durumu ve eğilimleri anlamak için istatistiki veri tabanları ve raporlar, yasal mevzuat dökumanları gibi ikincil niteliksel yazılı kaynaklar incelenmiştir. Bu çalışmada faydalanılan yasal mevzuat dökümanları, 6446 sayılı Elektrik Piyasası Kanunu, 5346 sayılı Yenilenebilir Enerji Kaynaklarının Elektrik Enerjisi Üretimi Amaçlı Kullanımına İlişkin Kanun, Bakanlar Kurulu Kararları, Mahkeme Kararları, Yönetmelikler, Tebliğler ve Enerji Piyasası Düzenleme Kurumu (EPDK) Kurul Kararlarıdır. İstatistiksel veri kaynakları ise Enerji ve Tabi Kaynakları Bakanlığı (ETKB) Bilgi Merkezi ve Yayınlarıdır.

Çalışmanın alan araştırmasında ise, Türkiye'de rüzgâr ve güneş enerjisine dayalı elektrik üretimi alanındaki uzmanlarla yarı yapılandırılmış derinlemesine mülakatlar gerçekleştirilmiştir. Alan araştırmasında, çok çeşitli görüş ve fikirler değerlendirilmek istendiğinden, farklı aktör gruplarından veri toplanmıştır. Mülakat yapılacak adayları seçerken, "araştırmanın amacına bağlı olarak stratejik olarak bilgi açısından zengin ve spesifik vakaların seçilmesi"ni sağlamak için amaçlı örnekleme (purposeful sampling) yöntemi kullanılmıştır (Patton, 2002: 243). Kilit uzmanlar, özel sektörde ve doğrudan kar amacı güden kuruluşlarda çalışan uzmanlar (Grup 1) ve özel sektör dışında ve doğrudan kar amacı gütmeyen kuruluşlarda çalışan uzmanlar (Grup 2) olmuştur. Yenilenebilir enerji alanındaki gerçekleştirdikleri ekonomik faaliyetler olan "üretim, düzenleme, danışma ve tedarik" faaliyetlerine göre de sınıflandırılmış ve alıntılanmışlardır.

Örnekleme sürecinde, kartopu (Patton, 2002) ve bilgiedinmeye yönelik seçim (Flyvbjerg, 2006) yöntemlerinden yararlanılmış ve toplam 57 adet görüşme gerçekleştirilmiştir. Bu görüşmelerden 34 tanesi özel sektördeki ( Grup 1), kalan 23 tanesi ise özel sektör dışındaki kuruluşlarda faaliyet gösteren aktörlerle (Grup 2) yapılmıştır (Tablo 1). İlk gruptaki aktörler genellikle şirket temsilcileridir ve büyük çoğunluğu rüzgar ve/ya güneş enerjisinden aktif olarak elektrik üretmekte olan veya elektrik üretim lisansı başvuruları yapmış şirketlerdir. İkinci gruptaki aktörler ise kamu kurumunda çalışan bürokratlar, üniversitede görevli akademisyenler ve kar amacı gütmeyen kuruluşlarda yer alan aktörlerdir. Tüm mülakatlar yüz yüze görüşme yöntemiyle Ağustos 2014-Mayıs 2015 arasında Ankara, İstanbul, İzmir, Antalya, Denizli, Balıkesir, Kayseri ve Gaziantep illerinde gerçekleştirilmiştir. Her bir mülakat ortalama bir ila iki saat arasında sürmüş, tüm mülakatlar kayıt cihazıyla kaydedilmiş ve hizmet alımı ile birebir yapılan deşifreleri ile analiz edilmiştir. Çalışmanın alan araştırması TUBITAK 1002 Programı kapsamında fonlanan 114K070 No'lu Proje ile fonlanmıştır.

Veri analizi yapılırken ham verinin analitik çerçeve yöntemi ile betimlendiği ve araştırma sorusunu cevaplamak için bulgu ve sonuçların teorik çerçeveye yerleştirilmesiyle yorumlandığı bir veri analiz sistematiği benimsenmiştir.

Tablo 1. Alan araştırmasında yapılan mülakat sayıları

\begin{tabular}{l|l|l|l|l}
\hline \multicolumn{1}{c|}{ Profil } & $\begin{array}{l}\text { Grup 1: Özel sektör kuruluşları } \\
\text { (Kar amacı güden) }\end{array}$ & $\begin{array}{l}\text { Grup 2: Özel sektör dışındaki kuruluşlar (Doğrudan kar amacı } \\
\text { gütmeyen) }\end{array}$ \\
\hline Faaliyet & Şirketler & $\begin{array}{l}\text { Kamu } \\
\text { Kurumları }\end{array}$ & $\begin{array}{l}\text { Sivil Örgütleri } \\
\text { Örodemik }\end{array}$ \\
\hline Üretim & 17 mülakat & - & - & $\begin{array}{l}\text { Tkplum } \\
\text { Kuruluşlar }\end{array}$ \\
\hline Düzenleme & - & 8 mülakat & - & - \\
\hline Danışma & 10 mülakat & 6 mülakat & 6 mülakat & - \\
\hline Tedarik & 7 mülakat & - & - & 3 mülakat \\
\hline
\end{tabular}


Patton (2002: 463), niteliksel veriyi analiz ederken "verinin kodlanması, örüntülerin bulunması, temaların etiketlenmesi ve kategori sistemlerinin geliştirilmesi"ni önermektedir. Kodlar, ham verinin ve alanda veri toplanırken tutulan notlar ve kaydedilen gözlemlerin, anlamlı ve bütünlüklü en küçük bölümlere ayrılması ve bu bölümlerdeki kavramların öne çıkarılması ile geliştirilen ve içeriğin yönetilebilir bir sınıflandırma şeması ile analiz edilmesine imkân tanıyan anlamlı en küçük başlıklardır (Patton, 2002; Corbin ve Strauss, 2008). Alan araştırması kapsamında kodlar, Corbin ve Strauss (2008)'in açık kodlama yöntemi kullanılarak, tek tek deşifrelerin okunması ve satır satır incelenmesi ile belirlenmiştir. Bu kodlama sürecinde, bilgisayar yardımlı bir nitel veri yönetimi ve analizi aracı olan "QDAQualitative Data Analysis Miner" Yazılımı kullanılmıştır†. Öncelikle tüm mülakat deşifreleri tek tek yazılıma yüklenmiştir. Mülakat formunun yapısına uygun olarak, toplanan veri beş başlık altında raporlanmıştır. Çalışmamız kapsamında kullandığımız bölümde engelleyici ve destekleyici faktörler rapor edilmiş ve bu iki alt başlıkta 81 kod çıkarılmıştır.

\section{Yazın Taraması: Yenilenebilir Enerji Teknolojilerinin Yayılmasını Etkileyen Faktörler}

Ülkelerin yenilenebilir kaynaklara dayalı enerji üretim performanslarının ardında çok çeşitli etmenler vardır. Jacobsson ve Bergek (2004), yenilenebilir enerji teknolojilerinin gelişme ve yayılmasını Almanya, İsveç ve Hollanda örneklerinde inceledikleri çalışmalarında ülke ve enerji kaynağı bağlamında farklı sonuçlara ulaşmışlardır. Almanya'nın Ar-Ge politikasını tasarlarken güneş pilleri ve rüzgâr türbinleri konusunda araştırmacı ve firmaları belli bir alana yönlendirmekten kaçınması, Hollanda'nın yine rüzgar türbinleri konusunda farklı araştırma alanlarını teşvik etmesi, çeşitliliği artırarak bu teknolojilerin gelişme ve yayılmasını olumlu etkilemiştir. Öte yandan İsveç, rüzgâr enerjisini nükleer enerjinin bir alternatifi olarak gördüğü için, türbin konusunda araştırmacı ve üreticileri büyük türbinlere yönlendirmiş ve sonuçta çeşitliliği desteklemediği için bu alanda başarılı olamamıştır. Almanya ve Hollanda rüzgâr enerjisi ve Alman ve İsveç güneş enerjisi vakalarında, erken dönemde endüstriyel firmaların teknoloji odaklı lobi faaliyetleri ile bu teknolojilerin meşruiyetini güçlendirmeleri başarıyı destekleyen bir diğer faktör olarak tanımlanmıştır. Öte yandan, İsveç rüzgâr enerjisi vakasında meşruiyetin neredeyse hiç olmaması, önemli bir Ar-Ge kaynak desteği olmasına rağmen, sektörün gelişimi önünden önemli bir engel teşkil etmiştir. Hollanda rüzgâr enerjisi sektöründe başlangıçta yakalanan olumlu eğilim ise sürdürülememiş ve teknolojinin yayılması kurumsal nedenlerle (özellikle bina kurulumlarındaki izin uygulaması) yavaşlamıştır ve Hollandalı üreticiler sektörden yavaş yavaş kaybolmaya başlamıştır. İsveç örneğinde de başlangıçta yakalanan meşruiyet, özellikle rüzgâr enerjisi politikalarının net olmamasından dolayı somutlaşamamıştır. Enerji sektöründeki yerleşik teknolojileri destekleyen güçlü lobilerin (advocacy coalition) dönüşüm sürecini engellemeleri, sektördeki tedarikçi firmaların akademi ve kamu Ar-Ge desteğinin önemli bir bölümüne sahip büyük üreticiler ile bağlantı kuramamaları, iş bölümü ve ölçek ekonomisinin gelişmemesi ve geleneksel yerleşik kurulum endüstrisinin yeni endüstriye uyum sağlayamaması yenilenebilir enerji teknolojilerinin yayılmasını ve piyasanın oluşmasını sekteye uğratmıştır.

Almanya'da yenilenebilir enerji teknolojilerinin yüksek yayılma hızı inceleyen Jacobsson ve Lauber (2006) çalışmasına göre, bu başarının ardındaki temel neden 1991 tarihli Teşvik Kanunu (Feed-in Law) ve 2000 tarihli Yenilebilir Enerji Kanunu (Renewable Energy Sources Act) ile somutlaşan Almanya'nın enerji sektöründeki düzenleme mekanizmasının spesifik özellikleri ve siyasi aktörlerin bu mekanizmayı kabul edip uygulamaya geçirmesini sağlayan fikirler ve süreçlerdir. Temel sav, yenilenebilir enerji teknolojilerinin (özellikle rüzgar türbinler ve güneş pilleri) yayılma hızlarının ülkeden ülkeye farklılık göstermesinin ardında yatan nedenin, izlenen politikaların yapısı ve bu politikaların tasarlandığı siyasi süreç (ve bu süreçte rol oynayan vizyon, değerler, farklı baskı gruplarının göreli güçleri, yeni teknolojinin meşruiyeti, öngörüler ve daha derinlikli tarihsel ve kültürel etkiler) olduğu varsayımıdır. Yine Almanya'nın yenilenebilir enerji kaynaklarından elektrik üretme sanayisinin gelişmesini başarılı bir örnek olarak inceleyen Wüstenhagen ve Bilharz (2006) çalışması da, bu başarının ardında politika amaçlarına ulaşma performansı yüksek politikaların izlenmesinin yattığını iddia etmektedir. Temiz elektrik üretimini talep eden belli bir tüketici yoğunluğunun olmasının da, elektrik üretiminde temiz kaynakların payını arttırıcı etkisinin olduğu ayrıca vurgulansa da, bunun etkisinin kısıtlı olduğu, asıl önemli etkenin politikalar olduğu belirtilmiştir.

Gan vd. (2007) çalışmasında ise, Almanya, Hollanda, İsveç ve Amerika'da yenilenebilir kaynaklara dayalı elektrik üretimi sanayinin gelişmesi ve yayılmasını sağlayan politikaların tasarlanması ve uygulamaya konması süreçlerini incelemişlerdir. Politika yapma sürecinde, hangi araçların kullanılacağına politika amaçları, fayda maliyet analizi ve sektördeki önemli aktörlerle fikir alışverişi ile karar verilmesi önerilmektedir (Gan vd., 2007: 145). Politika amaçları belirlenirken hedef belirleme, araçların seçilmesi, bu araçların ekonomik, mali ve düzenleme mekanizması açısından artı ve eksilerinin değerlendirilmesi, uygulamadaki karşılaşabilecek riskler ve aracın etkinliğini artıracak faktörlerin değerlendirilmesi gerekmektedir. İncelenen ülke örneklerinin tamamında, politikaları uygulamaya başladıkları dönem (genellikle 70ler) ve günümüz arasında politika önceliklerinde, "yoğun Ar-Ge desteği, yatırımın desteklenmesi ve tüketimin özendirilmesi" ekseninden "üretim ve tüketim teşviklerinin verilmesi ve piyasanın oluşumunun doğrudan desteklenmesi" eksenine bir kayma göze çarpmaktadır (Gan vd., 2007:152).

Sektörel yenilik sistemi yaklaşımını benimseyerek Avustralya, Almanya ve Japonya'da güneş pilleri sanayinin dönüşümünü karşılaştırmalı olarak inceleyen Marinova ve Balaguer (2009) çalışmasında, yeni bir teknolojinin ortaya çıkması ve yayılması etkileyen temel faktörlerin bilgi ve teknolojinin üretilmesi, aktörler ve aralarındaki etkileşim, kurumsal yapı ve işbirliği/ağ yapıları olduğu iddia edilmektedir. $\mathrm{Bu}$ çalışmaya göre, 1970'li yıllarda Avustralya'nın kamusal alanda yaptığı büyük ölçekli PV kurulumlarıyla dünyada lider konumundayken, 2000'lerle birlikte Almanya ve Japonya'nın gerisine düşmesinin sebebi Avustralya'da bir yenilenebilir enerji sektörel yenilik sisteminin oluşmamasıdır. Sistemik yapının oluşması ise yukarda belirtilen faktörlere bağlanmıştır. Örneğin, Avustralya'da yenilenebilir enerji teknolojilerini destekleyen 
aktörlerin ve etki gruplarının kurumsal altyapıyı bu teknolojiler lehine değiştirmek konusunda, Almanya'dakinin aksine güçlü olmaması bu başarısızlığın ardındaki ilk nedendir. Avustralya'da enerji sektöründeki yerleşik teknolojileri destekleyen etki gruplarının gücünün fazla olması bu anlamda gözden kaçırılmaması gerekli bir nokta olarak işaret edilmiştir. Öte yandan, Avustralya'nın başta şebekeye bağlı olmayan yenilenebilir enerji sistemlerde yakaladığı başarıyı şebekeye bağlı sistemlerin kurulumu ve yayılmasına aktaramaması da, Avustralya'nın yenilenebilir enerji sektöründe elde ettiği lider pozisyonu sürdürememesine sebep olmuştur. Diğer yandan Almanya ve Japonya, PV teknolojilerinde en hizlı büyüyen ülkeler olmuşlar ve "1995-2001 yılları arasında bu teknolojilerinin yayılma hızları sırasıyla \% 662 ve \% 893 olarak gerçekleşmiştir” (Marinova ve Balaguer, 2009: 463). Almanya'da sektörde güçlü Solar World ve RWE Schoot Solar firmalarının dikey ve üretimde bütünleşik bir yapı benimsemeleri, az sayıda aktörle işbölümü ile üretim yaparak piyasadaki dalgalanmaları engellemeleri ve daha bağımsız bir yapıda üretim yapmaları önemli bir avantaj olmuştur. Japonya'nın başarısının ardında ise, elektronik sanayindeki güçlü aktörlerin PV sektöründe çeşitliliğin yaratılması için önemli bir altyapı oluşturması olarak gösterilmiştir. Avustralya'da PV sektörünün gelişmesi daha çok akademik-bilimsel bir çevrede olmuşken, Almanya ve Japonya'da bu gelişme daha çok sanayi-iş çevreleri bağlamında gelişmiştir. Huang ve Wu (2009); Tayvan'daki rüzgar enerjisi vakasını incelerken, Almanya ve İsveç’teki rüzgar enerjisi sektörlerinin gelişim süreçlerini sırasıyla başarılı ve başarısız örnekler olarak ele almışlardır. Almanya'nın 1990 yılında 68 MW Kurulu gücünü 2007'de 22.300 MW'a yükseltmesinin ardında yatan nedenlerin "hükümetin Ar-Ge ve örnek kurulum programlarına yoğun kaynak sağlaması, paydaşlar arasında bilgi akışını sağlayan rüzgâr işbirliklerinin kurulması, piyasa oluşumunu sağlayan garantili elektrik satın alımı uygulamasının yapılması ve yerel rüzgar enerjisi üreticilerini destekleyen sanayi stratejilerinin geliştirilmesi” olduğu belirtilmiştir (Huang ve Wu, 2009:443). İsveç'te ise rüzgar enerjisinin yaygınlaşamamasının ardındaki nedenler "çeşitliliğin olmaması (sadece büyük ölçekli rüzgar türbinlerinin desteklenmesi), yenilenebilir enerjinin meşruiyetinin güçlü olmaması, piyasanın oluşum sürecinin yeterli performans gösterememesi ve rüzgar enerjisi ile ilgili sanayi politikalarının olmaması" şeklinde sıralanmıştır (Huang ve $\mathrm{Wu}$, 2009:444). A ̆g yapılarının, yeni enerji teknolojilerinin gelişmesi ve yayılması üzerindeki etkilerini inceleyen Musiolik ve Markard (2011)'a göre, ağ yapıları, teknoloji yenilik sistemlerindeki destek yapılarını (ilgili kamu Ar-Ge programları, mesleki eğitim modülleri, teknik rehber ve talimatnameler, aracı kurumlar, teknolojinin olumlu imajı) oluşturmak ve geliştirmek için stratejik olarak oluşturulmuşlardır. $\mathrm{Bu}$ çalışmaya, yeni teknolojilerin gelişmesi ile aktörlerin stratejik hamleleri arasındaki olumlu yönde güçlü bir ilişki olduğunu ve bu ilişkinin, sistemde faal olan aktörler tarafından ilgili ă̆ yapılarında ve işbirliği içinde eşanlı olarak üretildiğini söyler.

\section{Araştırma Sonuçları ve Tartışma}

Türkiye'de yenilenebilir enerji teknolojilerinin yayılmasını destekleyen ve engelleyen faktörler incelendiğinde, 40 adet destekleyici faktör, 40 adet de engelleyici faktör belirlenmiştir. $\mathrm{Bu}$ faktörler analiz edilirken gruplara ayrılarak incelenmiştir. Tsoutsos ve Stamboulis (2005) teknolojik gelişmelerin yayılmasının, eski teknolojinin yerine yenisini konulması, yani kısaca basit bir ikame etme davranışının incelenmesi olduğunu varsayarak hareket eden politika tasarım yaklaşımının sorunlu olduğunu belirtmiş, onun yerine yayılmanın önündeki engellerin anlaşılmasını vurgulayan Kemp vd. (1998) çalışmasından yola çıkarak, yayılmanın önündeki engelleri sınıflamışlardır. $\mathrm{Bu}$ çalışmada ise, Tsoutsos ve Stamboulis (2005) çalışmasındaki sinıflandırmalar da dikkate alınarak, sadece engelleyen değil, destekleyen faktörler de kapsamlı bir sınıflama ile ele alınmış ve çalışmamızda açık kodlama yöntemiyle elde edilen destekleyen ve engelleyen faktörler kendi içlerinde yedi ayrı başlık altında gruplanmıştır: Ekonomik, Fiziksel, Kurumsal, Psikolojik, Teknolojik, Siyasi ve Yönetimsel Faktörler.

\subsection{Ekonomik Faktörler:}

Elektrik üretimi, tüketimi ve dağıtımının kar, zarar, maliyet, finansman, rekabet gibi iktisadi etkilerini gösteren 13 destekleyici, 6 engelleyici faktör belirlenmiştir. Grup 1 tarafindan en sık ifade edilen destek "Yenilenebilir enerji teknolojilerinin maliyet açısından diğer teknolojilerle rekabet edebilir olması", en sık ifade edilen engel "Proje Finansmanı"dır (Tablo 2). Grup 2 tarafindan en sik tekrarlanan destek "Yenilenebilir enerji teknolojilerinin getirdiği yeni yatırım olanakları" iken, en sık tekrarlanan engel "Yüksek başlangıç yatırımı maliyetleri”" olmuştur.

Grup 1 uzmanlarına göre, gelişmekte olan bu teknolojilerin süreç içinde maliyet açısından rekabetçilik kazanmasının sebebi, diğer elektrik üretim teknolojilerinden farklı olarak kaynak girdi maliyeti olmamasıdır. Bir diğer unsur ise, bu teknolojilerin yatırım maliyetlerinin görece olarak daha hızlı azalmasıdır. $\mathrm{Bu}$ rekabetçi güç, eskiye nazaran yenilenebilir enerji teknolojileri sektörüne giren aktör sayısının artışı ve rekabetçi ortamın oluşmaya başlaması ile doğru orantılıdır. Tedarikçi bir uzmanımız, rekabetçi gücün önemine ve kazanılma biçimine sektördeki tedarik faaliyeti açısından yaklaşmış ve yerli teknoloji geliştiren ve üreten bir tedarikçi olarak, bu teknolojileri ilk geliştirmeye başlayan ülkelerle karşılaştırıldığında Türkiye'de maliyetler açısından rekabetçi gücü kazanmanın farklı yollardan gerçekleştiğini savunmuş ve buradaki rekabetçi gücün, üretim maliyetlerinin çok fazla düşmesinden değil, üreticilerin sektörde var olabilmek ve rekabet edebilmek için kar marjlarını olabildiğince aşağıya çekmesinden kaynaklandığını belirtmiştir.

Tablo 2. Ekonomik Faktörler

\begin{tabular}{l|l|l|c}
\hline & Faktör & $\begin{array}{l}\text { Grup 1: Özel sektör } \\
\text { kuruluşları (Kar amacı } \\
\text { güden) }\end{array}$ & $\begin{array}{l}\text { Grup 2: Özel sektör dışındaki } \\
\text { kuruluşlar (Doğrudan kar amacı } \\
\text { gütmeyen) }\end{array}$ \\
\hline Destekler & Maliyet açısından rekabet edebilme & $\mathbf{6}$ & $\mathbf{4}$ \\
\hline & Yüksek Elektrik Fiyatları & 5 & 0 \\
\hline & Artan elektrik tüketimi & 4 & 3 \\
\hline & İstihdam yaratma imkanı & 4 & 1 \\
\hline
\end{tabular}


Avrupa Bilim ve Teknoloji Dergisi

\begin{tabular}{l|l|c|c}
\hline & Yeni yatırım olanakları & 4 & $\mathbf{6}$ \\
\hline & Piyasa oluşumunda alınan geri bildirimler & 3 & 2 \\
\hline & Düşük operasyonel maliyetleri & 3 & 0 \\
\hline & Girdi (Kaynak) Maliyeti olmaması & 3 & 0 \\
\hline & Altyüklenicilerin aktif olması & 3 & 0 \\
\hline & Garantili Elektrik Alım Programı & 3 & 4 \\
\hline & İstekli yatırımcıların olması & 2 & 4 \\
\hline & İkame etkisi & 2 & 0 \\
\hline Engeller & Proje Finansmanı & $\mathbf{1 5}$ & 0 \\
\hline & Piyasa olşumundaki aksakllıklar & 5 & $\mathbf{5}$ \\
\hline & Finansal model olmaması & 5 & 1 \\
\hline & Yüksek kurulum maliyetleri & 2 & 0 \\
\hline & Yüksek Depolama Makiyetleri & 2 & 0 \\
\hline & Uzun geri dönüş süreleri & 1 & \\
\hline
\end{tabular}

Grup 1 uzmanlarına göre, ekonomik olarak yenilenebilir enerji teknolojilerinin yayılmasını olumsuz etkileyecek en kritik unsur ise "Proje Finansmanı"dır ve bu unsur çift taraflı bir sorun alanıdır. Çünkü proje finansmanın kolaylaşması için sektörün büyümesi ve olgunlaşması beklenirken, sektörün olgunlaşması için de proje finansmanına ihtiyaç duyulmaktadır. Tedarikçilerden bir diğerinin kendi sözleriyle "yumurta mı tavuk mu hangisi diğerinden çıkıyor diye sormak anlamsızlaşmaktadır”, çünkü işini büyütmek isteyen üretici böyle bir ortamda kendini yerinde saymak zorunda hissettiği için adım atmak zorlaşmaktadır. Çözüm olarak bankaların proje finansmanı konusunda özel bir düzenleme veya mekanizma geliştirilmesi beklentisi dile getirilirken, gelişmekte olan teknolojiler için de diğer sektörlerden bir farkı olmayan finansman modellerini kullanmanın yatırımları kolaylaştırmak yerine finansman bulmayı daha da zorlaştırdığı vurgulanmıştır. Danışmanlık alanından bir uzmanımız, bankaların geleneksel yöntemlerle (leasing gibi) finansman sağlamaya çalışıyor olmalarını eleştirmiştir. Çünkü ona göre bu model çok fazla işe yaramamaktadır. Kırsal kalkınma teşvikleri gibi modeller olduğunu, ama onlarda da \%50 hibe garantisi olduğunu, bu hibe olmadığında ise yatırım finansmanın da cazibesi kalmadığından yatırımın yapılmadığını belirtmiştir. Bir diğer danışmanlık şirketi çalışanı uzmanımıza göre, gelişmekte olan teknolojinin finansmanı, proje finansmanı şeklinde değil, varlık karşılığı finansman şeklinde kurgulanmaktadır. Fakat proje bazlı çalışan ve bu sektörde özellikle kritik rol oynayan danışmanlık şirketi gibi aracı kurumların sermaye birikimi gibi bir öncelikleri olmadığ yatırım için öz sermayelerinin olmasını beklemenin de anlamsız olduğunu, bu yüzden de varlık teminatıyla proje finansmanı sağlamanın düşünülemeyeceğini dile getirmiştir. Fakat bankaların garanti olarak bu yolu tercih etmelerinin yadsınamayacağını, bu yüzden finansman anlamında boşluklar doğduğunu belirtmiştir. Yine bir danışmanlık şirketi çalışanı, yenilenebilir enerji yatırımlarının geri dönüş süresi uzun yatırımlar olmasının, proje finansmanını daha önemli hale getirdiğini; uzun geri dönüş sürelerinin yatırımların proje finansmanını zorlaştıran yapısal bir unsur olduğu gözden kaçırılmadan finansman modellemesinde bütünlüklü bir değerlendirme yapmanın zorunlu olduğunu

‡Lisans almak amacıyla rüzgar enerjisi yatırımlarına girmeyi planlayan yatırımcılar, potansiyel yatırım sahalarında ölçüm yapmakla yükümlüdürler ve ölçüm direkleri bu yüzden dikilmektedir. Bu sayıda direk dikilmesi, en az 1500 e-ISSN: 2148-2683 vurgulamıştır. Öte yandan, yaşanan bu sorunların bir başka boyutu da gündeme gelmiş, bu sefer yatırım finansmanı elektrik tüketicileri açısından değerlendirilmiştir. Proje finansmanı yenilenebilir enerji kullanımını cazip hale getirecek şekilde kurgulamadığı için, tüketicilerin mevcut alışkanlıklarını ve elektrik üretim/tüketim rutinlerini değiştirmek için istekli davranmadıkları belirtilmiştir. Özetle, bahsedilen nedenlerle proje finansmanı Grup 1 uzmanları tarafından, sektördeki çeşitli sorunların kaynağındaki engelleyici faktör olarak işaret edilmiştir.

Grup 2 uzmanlarına göre yayılmayı destekleyen en önemli faktör yenilenebilir enerji teknolojilerinin getirdiği yeni yatırım olanaklarıdır. Düzenleme alanında çalışan uzmanlarımızdan birine göre, artan elektrik talebi ile birlikte, bu talebi karşılamak için yeni kurulumlar gereklidir ve yenilenebilir enerji kaynaklarında da büyük bir potansiyel vardır. Bu, sektörde yeni yatırım olanaklarını doğurmaktadır. Öte yandan, bu potansiyelin realize olması için sektörden gelen büyük bir talebin olduğu da açıktır. $600 \mathrm{MW}$ güneş enerjisi lisans yatırımı için $8000 \mathrm{MWl}$ k bir başvuru gelmesi ve yeni açılan rüzgar santrali kurulum başvurularında yaklaşık 1 sene önceden 1500 tane ölçüm direğ $\mathrm{i}^{\star}$ dikilmesi bunun kanıtıdır. Danışmanlık alanında çalışan uzmanlarımızdan biri, enerji sektörünün çok karlı ve gelişen bir sektör olduğunu, yenilenebilir enerjinin de artan oranlarla gelir getirdiğini belirtmiş, bu alandaki yatırım olanaklarına da vurgu yaparak şöyle demiştir:

"Benim de hayalim. Keşke bir santralin \% 20'si de benim olsaydı. Çok isterim. Çünkü hazır para var, 10 yıl alım garantisi var. Az buz bir şey değil, düşünün, bir ürün üretiyorsunuz. Ve satma derdiniz yok, yani marketing tarafi yok, zaten alıcı hazır e sabit bir fiyattan, hem de dolar üzerinden alım garantisi veriyor"

Kamu sektöründe düzenleyici rolündeki bir uzmanımız ise, çevre ülkelerdeki kurulum ve yatırım olanaklarının yerli teknoloji geliştirmemiz durumunda daha çok önem kazanacağını, örneğin Kıbris, İran, Irak gibi ülkelerde kendi teknolojilerimizi kullanabileceğimiz yeni yatırımlar yapabileceğimizi söylemiştir.

Grup 2 tarafından en çok dile getirilen engel ise, "Yüksek başlangıç yatırımı maliyetleri"dir. Düzenleme alanından ayrı yatırım projesinin olduğunun göstergesi kabul edilebilir ve bu yüksek bir rakamdır. Çünkü söz konusu dönemde dağıtılması planlanan rüzgar enerjisi lisans miktarı 3000 Mwdır. 
uzmanlarımızdan birine göre, yenilenebilir enerji kurulum ve inşaatının zor olması ve teknolojinin pahalı olması bu yatırımları, diğer kaynaklara yapılan yatırımlarla rekabet etmek açısından riskli hale getirmektedir. Öte yandan, yüksek ilk yatırım maliyeti ve karşılaştırmalı olarak düşük verimli olmalarının birer dezavantaj olduğu, bu sebeple YEK yatırımlarının "zengin işi”" olduğu ifade edilmiştir. Danışmanlık faaliyeti olan uzmanlarımızdan biri ise, yüksek ilk yatırım maliyetlerinin uzun yatırım geri dönüş sürelerini daha da uzattığını, bunun da hızlı para kazanmak isteyen sabırsız yatırımcıların yatırım yapmalarını engellediğini belirtmiştir.

\subsection{Fiziksel Faktörler:}

Fiziksel faktörler grubu ise, ülkenin mevcut fiziksel koşullarına bağlı olarak ortaya çıkan engelleyici ve destekleyici faktörlerdir ve toplamda 4 destekleyici, 2 engelleyici faktör belirlenmiştir (Tablo 3). Grup 1 ve Grup 2, aynı engelleyici ve destekleyici faktörleri vurgulamışlardır. Bu iki uzman grubu tarafından öne çıkarılan destekler "Türkiye'de Yenilenebilir Enerji Kaynaklarının bol olması" ve "Yenilenebilir Enerji kaynaklarının yerli kaynak olması"dır. Uzman gruplarımızın ikisi tarafindan da en çok dile getirilen fiziksel engel unsuru ise "Yenilenebilir enerji kaynaklarına dayalı olarak üretilen elektriğin son kullanıcıya ulaşmasında gerekli altyapı olanaklarındaki yetersizlikler"dir.

Tablo 3. Fiziksel Faktörler

\begin{tabular}{l|l|c|c}
\hline & Faktör & $\begin{array}{l}\text { Grup 1: Özel sektör } \\
\text { kuruluşları (Kar amacı } \\
\text { güden) }\end{array}$ & $\begin{array}{l}\text { Grup 2: Özel sektör dışındaki } \\
\text { kuruluşlar (Doğrudan kar } \\
\text { amacı gütmeyen) }\end{array}$ \\
\hline Destekler & Kaynağın bol olması & $\mathbf{5}$ & $\mathbf{2}$ \\
\hline & Kaynağın yerli kaynak olması & 5 & 2 \\
\hline & Sağlık ve çevre koşullarında iyileşme & 4 & 1 \\
\hline & Fosil kaynakların yetersiz olması & 0 & $\mathbf{1 5}$ \\
\hline Engeller & Fiziksel Altyapıdaki eksiklikler & $\mathbf{1 5}$ & 6 \\
\hline & Doğa koşullarına bağlılık & 8 & \\
\hline
\end{tabular}

Grup 1 uzmanları, Türkiye'nin Avrupa'da İspanya'dan sonra en çok güneş alan ikinci ülke olduğunu ve Türkiye'deki kaynakların zengin olduğunu defaatle vurgulamışladır. Özellikle Konya ve onun altındaki bölgelerde güneş enerjisi potansiyelin çok fazla olduğu belirtilirken, bu bölgede güneşlenme süresi birçok Avrupa ülkesiyle kıyasladığında daha uzun olduğu için, güneş santralleri o ülkelere kıyasla daha verimlidir. Özellikle Konya ovasının başka bir amaçla da kullanılmasının çok mümkün olmadığ 1 ve o bölgede sırf bu sistemlere özel trafo merkezleri ve devasa güneş enerjisi santralleri yaparak, belli bir süre kendi enerjisini güneşten karşılayan ve yurt dişına elektrik satacak hale gelecebilecek bir bölge önerilmiş ve Konya Bölgesinde bugün 3000 MW büyüklüğündeki Yenilenebilir Enerji Kalkınma Alanı girişimi o günden öngörülmüştür.

Uzman gruplarımızın ikisi tarafından da öne çıkarılan fiziksel engel ise "Yenilenebilir enerji kaynaklarına dayalı olarak üretilen elektriğin son kullanıcıya ulaşmasında gerekli altyapı olanaklarındaki yetersizlikler"dir. Grup 1'deki uzmanların altyap1 sorunlarına yaklaşımları kendi yatırımlarının seyri açısından olmuştur. Örneğin danışmanlık alanında faaliyet gösteren bir uzmanımız, altyapıdaki eksiklerinin temel kaynağında dağıtımla ilgili altyapı sorunları olduğunu belirtmiştir. Şebekeye bağlanma açısından, kapasiteler önceden ilan edildiği ve izin süreçlerine tabi olduğu için bir sorun olmayacağını, asıl sorunun dağıtım sistemi altyapısından kaynaklanabileceğini vurgulanmıştır. İlaveten, yenilenebilir enerji kaynakları sisteme bağlandıkça dağıtımla ilgili "İlk ekipman ihtiyaçları ve gerilim trafosu ihtiyaçları" ortaya çıkabileceği ve bunların sistemi aksatmayacak şekilde giderilmesi için ise, dağıtım şirketlerinin kalifiye insan kaynağının olması gerektiği işaret edilmiştir. Elektrik üreticisi bir uzman ise, kendi yatırım deneyimlerinden örnek vermiştir ve kendi rüzgar

${ }^{\S}$ Sektörden gelen bu talepler, TEİAŞ yetkilileri tarafından değerlendirilmiş ve 2015 yılı Ocak ayından itibaren Lisanssız RES ve GES başvurularına ayrılacak trafo kapasitelerini her ayın başında web sitelerinde yayımlamaya başlamıştır e-ISSN: 2148-2683 lisanslarını 2002'de almalarına rağmen uzun bir süre, üretime geçebilmek için TEİAŞ'ın bu bölgeye yaptığı iletim hattını tamamlamasını beklediklerini aktarmıştır. TEİAŞ'ın bu sorunu çözmek için bölgede yatırımı olan şirketlerden kurulu güçlerine göre para topladığını, oraya üç tane trafo merkezi ve enerji iletim hattı yaptığını, sonrasında bu yatırım bedellerini kendi yatırım harcamalarından düştüğünü belirtmiştir. Bir başka üretici ise, yine kendi deneyimlerini aktarmış; yatırımın şebekeye bağlanması için gerekli iletim hatlarının kendilerinin yaptığını; yatırımları için yaklaşık 55 kilometre de hat inşa ettiklerini belirtmiş, böyle bir altyapı yatırımının da ek bir maliyet ve başlangıç yatırımında bir artış getirdiğini söylemiştir. Büyük bir elektrik üreticisi olan yatırımcı uzmanlarımızdan birine göre ise bu tür altyapı sorunları, YEK elektriğinin enerji sistemine entegrasyonu konusunda altyapının hazırlıksız olmasından kaynaklanabilmekte fakat bunları görebilmek ve önlem alabilmek için öncelikle sisteme YEK elektriğini bağlayarak sonrasında somut düzeltmeler yapılması gerekmektedir. Lisanssız elektrik üretim başvuruları öncesinde uzun ve detaylı bir hazırlık süreci olduğunu, özellikle arsayla ilgili çok ciddi anlaşmalar yapmanız gerektiğini belirten bir diğer elektrik üreticisi uzmanımız, başvuruyu yaptığınızda "trafoda kapasite yok cevabı alıp yatırımı durdurmak zorunda kalabilme ihtimali" olmasının yatırımları daha riskli hale getirdiğini söylemiş ve trafo kapasitelerinin şeffaflaşması gerektiğini belirtmiştir ${ }^{\S}$.

Grup 2'deki uzmanlara göre fiziksel engellerin kaynağ 1 yenilenebilir elektriğin doğasının getirmiş olduğu aksaklıklardır. Düzenleme kurumunda çalışan uzmanımıza göre, YEK yatırımlarında, uzun dönemli bir planlama ve ilave ilettim hattı yatırımı gerekmesi doğaldır ve altyapıdaki iletim hattı eksikliğini yatırımcının kapatmasını arz güvenliğine katkı olarak 
değerlendirilmelidir. Altyapı konusunda planlama yapılmasına rağmen hızlı aksiyon alınmasının zor olduğu, şebekeye bağlanan yenilenebilir santral miktarı arttıkça şebekenin de daha fazla zorlanacağını vurgulanmıştır.

\subsection{Kurumsal Faktörler:}

Kurumsal faktörler, Bergek vd. (2008)'de belirtildiği gibi yenilenebilir enerji teknolojilerinin yayılacağı bağlam ve çevredeki kültürel ortam, normlar, kurallar, düzenlemeler ve rutinlerden kaynaklanan faktörlerdir ve çalışmamızda 5 destekleyici, 6 engelleyici faktör belirlenmiştir (Tablo 4). Hem Grup 1 hem de Grup 2 uzmanları tarafindan en sık dile getirilen destek "Olumlu Lobi ve savunma grubunun faaliyetleri"dir. İki grup için de öne çıkan engelleyici kurumsal faktör ise "Kamu kurumları arasında koordinasyon olmaması"dır.

Tablo 4. Kurumsal Faktörler

\begin{tabular}{|c|c|c|c|}
\hline & Faktör & $\begin{array}{l}\text { Grup 1: Özel sektör } \\
\text { kuruluşları (Kar amacı } \\
\text { güden) }\end{array}$ & $\begin{array}{l}\text { Grup 2: Özel sektör } \\
\text { dışındaki kuruluşlar } \\
\text { (Doğrudan kar amacı } \\
\text { gütmeyen) }\end{array}$ \\
\hline \multirow[t]{5}{*}{ Destekler } & Olumlu Lobi ve savunma Grubu & 17 & 7 \\
\hline & Uzmanlarla işbirliği yapma & 3 & 0 \\
\hline & Yenilenebilir enerji kaynaklarına tanınan & 1 & 2 \\
\hline & Dünyada Yenilenebilir kaynaklara artan & 1 & 0 \\
\hline & İşbirliği ve ağ yapıları & 0 & 2 \\
\hline \multirow[t]{6}{*}{ Engeller } & $\begin{array}{l}\text { Kamu kurumları arasında } \\
\text { koordinasyon olmaması }\end{array}$ & 17 & 16 \\
\hline & Yeni teknoloji ile uyumda sorunlar & 7 & 2 \\
\hline & Karş1 lobi & 6 & 4 \\
\hline & İşbirliğinde sorunlar & 3 & 3 \\
\hline & Kritik kütlenin olmaması & 0 & 1 \\
\hline & Ağ yapısında sorunlar & 0 & 2 \\
\hline
\end{tabular}

Grup 1 uzmanları; yenilebilir enerji teknolojilerinin yayılması için özellikle dernek eliyle yürütülen lobi faaliyetlerinin önemine dikkat çekmişlerdir. "Oyuncuların birbirleriyle olan kişisel ilişkilerinden ziyade bir takım kuralları koyan, regüle eden, bunları yöneten derneklerin varlığını" çok önemsediğini belirten bir tedarikçi şirket temsilcisi; Türkiye'de özellikle güneş enerjisi sektöründe "kamu kurumlarıyla görüşecek, üniversitelerle işbirliğinde olacak ve bunları kendi üreticileriyle birlikte yapacak" derneklerin varlığının önemine vurgu yapmıştır. Aktif bir danışmanlık şirketi sahibi uzmanımız ise lobi faaliyetlerine "ortak akıl oluşturmak" olarak baktığını, bu konuda rüzgar enerjisi sektöründe Türkiye Rüzgar Enerjisi Birliği (TÜREB)'in bunu 'ç̧ok hızlı organize olabilen ve her platforma taşıyabilen iyi çalışan bir kuruluş" olduğunu belirtmiştir. Rüzgar enerjisinde böyle güçlü bir lobi faaliyeti oluşması ise, sektörün gelişip belli bir noktaya ulaşmasına bağlanmıştır. Sektör büyüdükçe, sorunların da arttığı ve eskiden tek bir kişinin sorunu olan konunun sektör büyüdükçe onlarca yatırımcıyı etkilemesinin, lobi faaliyetlerinin önemini daha da $\operatorname{arttırdığ~}$ sonucuna varmışlardır. Derneklerin lobi faaliyetlerini yürütürken asıl amaçlarının sektör adına hareket etmek olduğu, lobi faaliyetlerinin ayrı bir mesai ve profesyonel olarak uzmanlaşma gerektirdiği için birer birer paydaşların yapması yerinde daha güçlü bir şekilde birlikte hareket etmeye olanak tanıdığını vurgulanmıştır.

Grup 2 uzmanları ise, lobi faaliyetleri ile edinilmiş bir kazanım olarak şebekeden bağımsız lisanssız santrallerde kurulu güç üst sınırının artırılmasını örnek göstermiş, lobi faaliyetleri ile en azından kamuoyunun gündeminde olmayan konuları görünür kıldıklarını ve mücadele konusu yaptıklarını belirtmişlerdir. Lobi faaliyetleri gerçekleştirecek derneklerde profesyonel ve tarafsız bir yönetim kurmak ve şeffaflık ön plana çıkarılmıştır.

Engeller incelendiğinde ise, Grup 1 uzmanlarına göre koordinasyon sorunu yayılmanın önünden en önemli engeldir. Elektrik üreticisi bir uzmanımız, bir kamu kurumunun uyguladığ 1 yatırım prosedürü diğer kamu kurumununkini takip eder şekilde düzenlenmediği için süreçte kümülatif ilerleme kaydedilemediğini, bazen yatırımcını bir ileri bir geri gitmek zorunda kalabildiği belirtmiştir. Bir diğer elektrik üreticisine göre, çok sayıda kurumun sürece bir sistematik çerçevesinde dahil olmaması ve aralarında iletişimsizlik olması, alınan lisansın bile realize olmasını engellemektedir. Katılımcılarımız tarafından verilen çarpıcı bir örnek de kurulum lisansı olan bir bölgede başka bir devlet dairesinin santral kurulumuna izin vermemesi; ikisi de devlet kurumu olan bu organizasyonların aralarındaki söz konusu iletişimsizliğin yatırımı durdurduğudur.

Grup 2 temsilcileri de benzer sorunu gündeme getirmişlerdir. Örneğin büyük şirketlere danışmanlık veren bir katılımcımız, sırf bu yüzden kendi takip ettikleri lisans başvurusu değerlendirmesini, sürecin tamamlanmasına yakın düzenleyici kurum tarafından yapılan bir değişiklik nedeniyle tekrar yapmak zorunda kaldıklarını, değerlendirmenin sonuçlanmasının bu sebeple çok zaman aldığını söylemiştir. Benzer bir durumun tekrar yaşanmaması için YEK sürecinin değerlendirilmesi hakkında metodolojik bir çalışma yapmayı düşündüklerini ve "tek elden koordinasyonunu sağlamak" için planlama yaptıklarını belirtmişlerdir. Düzenleme kurumu temsilcisi ise, koordinasyon sorununu "mevzuatlar arası uyum sorunu" olarak tanımlamış, bu sebeple yatırımcıların ağ yapıları ve ilişkiler üzerinden pratik çözümlere ulaştığını ve işin ilerlediğini belirtmiştir. Özel sektör dışında faaliyet gösteren bu grupta yer alan bir danışman ise bir 
kurumun beklentisinin diğer kurumun uygulamasını karşılamadığını; bu sebeple işlerin yavaşladığını belirtmiştir. Bu bağlamda koordinasyon sorununun biraz da kurumlar arasında süreci yönetimde alınan inisiyatif ve yetki çatışmalarından kaynaklandığını, bir alt üst ilişkisi veya belirgin bir görev dağılımı da olmadığı için iş yaptırmakta zorlanıldığını, bu sorunun kurumlar bir araya daha sık geldiklerinde çözülebileceği söylenmiştir.

\subsection{Psikolojik Faktörler:}

Psikolojik faktörler, çalışmamız kapsamında aktörlerin yenilenebilir enerji teknolojilerini kullanmalarında, içinde bulundukları ortamın koşullarından etkilenerek geliştirdikleri tepkilere doğrudan neden olan faktörler olarak tanımlanmıştır ve 1 destekleyici, 4 engelleyici faktör belirlenmiştir (Tablo 5). "Komşu etkisi" olarak adlandırılan destekleyici faktör piyasa aktörlerinin, yakınlarında yapılan bir yenilenebilir enerji yatırımından veya bu yatırımı yapanların olumlu değerlendirmelerinden etkilenerek, yenilenebilir kaynaklardan elektrik üretim faaliyetine daha sıcak bakmaları olarak tanımlanmıştır. Bu destek faktörü, mülakatlarımız sırasında iki uzman grubunda da en sik dile getirilen bu sinifta yer alan tek faktördür. Yatırım ve üretim sürecinde "Hissedilen belirsizlik" ise, yine iki grup tarafından da en sık ifade edilmiş engelleyici faktör olmuştur.

Tablo 5. Psikolojik Faktörler

\begin{tabular}{l|l|c|c}
\hline & Faktör & $\begin{array}{l}\text { Grup 1: Özel sektör } \\
\text { kuruluşları (Kar amacı } \\
\text { güden) }\end{array}$ & $\begin{array}{l}\text { Grup 2: Özel sektör } \\
\text { dışındaki kuruluşlar } \\
\text { (Doğrudan kar amacı } \\
\text { gütmeyen) }\end{array}$ \\
\hline Destekler & Komşu etkisi & $\mathbf{6}$ & $\mathbf{5}$ \\
\hline Engeller & Belirsizlik & $\mathbf{1 7}$ & $\mathbf{9}$ \\
\hline & Hazırlıksız işe koyulmak (Kervanı yolda & 8 & 1 \\
\hline & Farkındalık olmaması & 7 & 6 \\
\hline & Psikolojik Bariyerler & 3 & 3 \\
\hline
\end{tabular}

Grup 1 uzmanlarına göre, komşu etkisi özellikle lisanssız öz tüketimin gelişiminde etkili olmuş; çatılarda kurulmuş ve işleyen uygulamaların görülmesinin, halkı ve yatırımcıları olumlu etkilediği belirtilmiştir. Kurulum konusunda danışmanlık veren fakat çatı kurulumu olmayan şirket temsilcileri, kendilerinin neden hala kurmadıklarının sık sık sorulduğunu, çatıları müsait olmayan bu şirketlerin bu nedenle kurulum yapmadıklarını her firsatta anlattıkları belirtilmiştir. Küçük bir yatırımcı olan bir elektrik üreticisi katılımcımız, enerji yatırımlarında bir tür modanın oluştuğunu ve yatırımcıların bundan etkilendiğini söylemiştir. 2003'te hidrolik santraller, 2007'de de rüzgar enerjisi santralleri için benzer bir eğilim olduğu, bazı yatırımcıların da fizibilite hesapları bile yapmadan bu akıma kapılarak yatırıma giriştiklerini örnek verimiştir. Hatta bazı yatırımcıların, yatırım yapabilmek için o dönemde alınmış lisansların şu anda kurulum imkanı olarak değerlendirdikleri, bunların içinde hiç kurulamayacak lisanslar olduğu ve bu lisansların da bu şekilde alınmış olduğunu düşündükleri belirtilmiştir. Bir diğer elektrik üreticisi katılımcımız ise komşu etkisinin hem olumlu hem de olumsuz sonuçları olabileceğini söylemiştir. Sektör özellikle güneş enerjisi henüz başlangıç aşamasında olduğundan; kötü bir hazırlık süreci ile yatırım kararı almış bir girișimcinin olumsuz deneyiminin tüm sektöre mal edilebilme ihtimalinin de olduğu, bunun da olumsuz bir etkilenme yaratarak diğer girişimcileri caydırabileceği işaret edilmiştir. Öte yandan, danışmanlık faaliyeti yürüten katılımcılarımızdan biri, olumlu deneyimleri olan insanların da aktif bir şekilde kamuoyunu bilgilendirmelerinin yeni kurulumlar yapılması açısından önemli katkı sağlayacağını söylemiştir.

Grup 2 uzmanlarına göre de en önemli psikolojik destek komşuda görmekten gelmektedir. Bizim toplumumuzda "görerek algılayan bir yapı" olduğu ve bu sebeple özellikle rüzgar ve güneş alanındaki kurulumları destekleyerek sayılarının hızla artmasını ve topluma örnek oluşturmasını istediklerini belirten bir danışman katılımcımız olmuştur. Öte yandan kamu kurumlarından birinde, kurum temsilcisi olarak çalışan bir katılımcımız, kurulum onayına gittiklerinde benzer eğilimi gözlemlediğini bildirmiştir. Kendi çatılarına lisanssız güneş enerjisi santrali kurmuş fabrikalarda tesis kabullerine gittiğinde, komşu fabrikalarda da kabulü incelemeye gelenlerin çok olduğunu belirtmiş ve bizde "komşum yapsın bir bakayım, kazanıyor mu kazanmıyor mu" mantığ olduğunu söylemiştir. Kayseri bölgesinde çalışan bir kamu görevlisi katılımcımız ise kendi bölgelerinde bunun en önemli destekleyici unsur olduğunu, bu bölgede lisanssız santrallerin para kazandırdığının kabul edilmesinin diğer yatırımcılar üzerinde çok önemli bir motivasyon kaynağı olarak kabul edildiğini söylemiştir. Türkiye Meteroloji Kurumu'nda çalışan bir katılımcımız ise bu konuda kamu kuruluşlarının öncü rol oynayarak, sembolik dahi olsa güneş enerjisi kurulumları yapmalarının, lisanssız küçük tesislerin yaygınlaşmasında çok etkili bir yöntem olabileceğini belirtmiştir.

Engeller değerlendirildiğinde ise, Grup 1 içinde yer alan ve avukat olup danışmanlık veren bir katılımcımız yatırımcı için en büyük sorununun belirsizlik olduğunu; yasa koyucularının süreç başladıktan sonra mevzuatı değiştirmelerinin sektörü olumsuz etkilediğini söylemiştir. Yatırım ortamındaki belirsizliğin; yatırımcılar için olduğu kadar dağıtım ve iletim şirketleri için de tedirginlik yarattığı; çünkü atılan adımların teknik sonuçlarının kestirilemiyor olduğu danışmanlık alanında faaliyet gösteren bir şirket temsilcisi vurgulamıştır. Güneș enerjisi alanında verilen ilk lisanslardan birine sahip olan bir şirket temsilcisi katılımcımız, özellikle lisanssız rüzgar ve güneş enerjisi santral yatırımların geleceği hakkındaki belirsizliğe dikkat çekmiştir. Lisanssız yatırımlarda üst sınır $1 \mathrm{MWdır**;} \mathrm{fakat} 1 \mathrm{MW}, 1 \mathrm{MW}$ yan yana 
lisanssız enerji santrali başvurusu yaparak büyük bir santral kurmanız mümkündür. Lisanssız santrallerde, mevzuat ilk çıktığında yer alan öztüketim zorunluluğu, yani tesiste üretilen elektriğin belli bir miktarının tesiste tüketilmesi gerekliliği, sonradan yürürlükten kaldırılmış ve devletin bu tesislerden elektrik satın alma garantisi 10 yıl ile sınırlanmıştır. Elektrik üreticisi ve yatırımcı olan iki uzmanımız da, bu uygulamalara dikkat çekmiş, lisanssız tesislere öztüketim zorunluluğunun tekrar getirilip getirilmeyeceği belirsizliğinin ciddi bir yatırım riski unsuru yarattığını, sırf bu yüzden kendilerinin güneş enerjisi ön lisansına sahip olmalarına rağmen güneş enerjisinde lisanssız yatırım yapmayı hiç düşünmediklerini söylemiştir. Hem rüzgar hem de güneş enerjisi alanında yatırımları olan bir temcilcimiz de öztüketim zorunluluğu konusundaki belirsizliğin riskine dikkat çekerek; yatırımcıların daha sağlam adımlar atmak için çok temkinli ilerlediklerini belirtmiştir. Tedarikçi bir katılımcımız ve ve üretici katılımcımız, sektördeki diğer bir belirsizlik unsuru olarak, lisanslı güneş enerjisi santrallerinin henüz tamamlanmamış olmasını işaret etmişlerdir ${ }^{\dagger \dagger}$. Bu belirsizliğin özellikle yabancı yatırımcıların gözünden sektörün cazibesini çok olumsuz etkilediğini söylemişlerdir. $\mathrm{Bu}$ durumda yabancıların daha fazla sektörde kalmak istemedikleri, kendileri de yabancı bir şirkette çalışan bir katılımcımız ise üst yöneticilerine sırf bu belirsizlik yüzünden sektörün gidişatı hakkında sağlıklı bilgi veremediğini belirtmiştir. Yabancı sermaye sahiplerinin de bu belirsizliği tolere edemediği için sektörden çekildiği, yerli yatırımcılar için düşük faizle finansal kaynak sağlayan yabancı sermayenin sektörden ayrılmasının da avantajlı finansman imkanından yararlanmayı zorlaştırdığı belirtilmiştir. Yabancı bir tedarikçi şirkette çalışan katılımcımız, yenilenebilir enerji sektörünün gelişimi konusunda bu kadar çok belirsizliğin olmasının aslında yapay olduğunu; siyasi irade isterse bunu çok rahat giderebileceğini söylemiştir.

Grup 2 uzmanları ise yine belirsizliğin önemli bir engelleyici unsur olduğunu söylemişler, Grup 1 tarafindan vurgulanan bazı noktaları onlar da dile getirmişler ama buna ek olarak farklı bir belirsizlik unsuru olarak rüzgar ve güneşin doğa koşullarına fazla bağlı olmasını göstermişlerdir. TEİAŞ çalışanı bir katılımcımız, zaten rüzgar ve güneş kaynaklarının sürekliliği konusunda diğer kaynaklarla karşılaştırıldığında ortaya çıkan bir belirsizlik unsuru olduğunu, bunun da sektör açısından bir dezavantaj yarattığını söylemiştir. O dönemde ismi Yenilenebilir Enerji Genel Müdürlüğü olan Enerji İşleri Genel Müdürlüğü'nde çalışan bir uzmanımız ise, aynı belirsizlik unsuruna dikkat çekip, enerji piyasa fiyatlarının ve arz -talep dengesinin belirlendiği Piyasa Mali Uzlaştırma Mekanizmasının işleyişini ${ }^{\star \ddagger}$ anlatarak böyle bir işleyişte belirsizliğin daha da kritik bir unsur haline geldiğini söylemiştir. Hazırlıkları tamamlanmış olan gün içi piyasasının devreye girmesiyle, rüzgar ve güneş için kritik olan bu belirsizlik unsurunun etkisinin azaltılacağ

\subsection{Teknolojik Faktörler:}

Teknolojik faktörler, yenilenebilir enerji kaynaklarına dayalı elektrik üretimi teknolojilerinin geliştirilmesi ve kullanılması ile ilgili tüm etmenleri kapsamaktadır ve çalışmamız kapsamında toplamda 6 destekleyici, 9 engelleyici faktör belirlenmiştir (Tablo 6). Grup 1 temsilcileri tarafindan en sık söylenen destek "Kilit Aktörlerin Teknoloji Geliştirme Stratejileri”; engel ise "Sektördeki aktörlerde (özellikle teknik) bilginin eksik olması"dır. Grup 2 temsilcilerine göre en sık dile getirilen destek "Üretentüketici (Prosumer) Etkisi", engel ise "Sektördeki aktörlerde (özellikle teknik) bilginin eksikliğii"dir.

Tablo 6. Teknolojik Faktörler

\begin{tabular}{l|l|c|c}
\hline & Faktör & $\begin{array}{l}\text { Grup 1: Özel sektör } \\
\text { kuruluşları (Kar amacı } \\
\text { güden) }\end{array}$ & $\begin{array}{l}\text { Grup 2: Özel sektör } \\
\text { dişındaki kuruluşlar } \\
\text { (Doğrudan kar amaci } \\
\text { gütmeyen) }\end{array}$ \\
\hline Destekler & Kilit aktörlerin teknoloji geliştirme & $\mathbf{1 1}$ & 3 \\
stratejileri & 7 & 4 \\
\hline & Teknoloji geliştirme yolları & 5 & 2 \\
\hline & Bilgi transfer kanalları & 5 & $\mathbf{5}$ \\
\hline & Üretentüketici etkisi & 1 & 3 \\
\hline & Sektorel bilginin aktarımı & $\mathbf{1 2}$ & $\mathbf{7}$ \\
\hline Engeller & Teknik Bilgi eksikliği & 9 & 3 \\
\hline & Kalifiye teknik eleman eksikliği & 5 & 2 \\
\hline & Teknolojideki bazı verimsizlikler & 3 & 2 \\
\hline & Çin Etkisi & 3 & 1 \\
\hline & Nükleer Güç & 1 & 0 \\
\hline & İthal teknoloji & 1 & 1 \\
\hline & Elektrik üretim teknolojisindeki sorunlar & 0 & 1 \\
\hline & Yenilenebilir enerjinin bir baz yük & 0 & \\
\hline & Teknolojik olarak olgunlaşmamış olmak & & \\
\hline
\end{tabular}

\footnotetext{
† Çalışma yapılırken 2014-2015 yılları arasında lisans başvuruları henüz tamamlanmamıştı. Güneş enerjisi için $600 \mathrm{MW}$ olarak açılan lisans başvuruları, başvurular açıldıktan 2 sene sonra 2015 senesinde tamamlanmıştır ve lisans kurulumları konusundaki çalışmalar da hala devam etmektedir.

林 R4 bu işleyişi şu şekilde özetlemiştir: PMUM'da işlem yapabilmek için gün içinde saat 11.30a kadar önümüzdeki 24 saat için üretim değerlerinin girilmesi e-ISSN: 2148-2683
}

gerekir. Bu girdiginiz değerlerin üretimini sağlamanız ve bu miktarda enerjiyi piyasaya satmanız gerekir. Eğer girdiğiniz elektrik miktarını sağlayamazsanız aradaki farkı cezalı olarak odersiniz, fazlasini satarsanız ise en düşük fiyat üzerinden para kazanmış oluyorsun. 
Grup 1 uzmanlarının teknoloji geliştirme stratejileri, yenilenebilir enerji teknolojilerinin yayılması sürecinde destekleyici bir rol oynamaktadır. Özellikle üretici ve tedarikçi kilit uzmanların önemli bir çoğunluğu kendi teknoloji geliştirme faaliyetlerini yürütmektedir. Bunlardan birisinde çalışan katılımcımız, güneş enerjisi alanında ana akım teknoloji geliştirme faaliyeti olan güneş hücresi çalışmalarından farklı bir teknoloji geliştirme çalışması yürütmekte olduklarını belirtmiştir. $\mathrm{Bu}$ çalışmasıyla TÜBİTAK'tan destek almışlardır. Finansal desteğin sağlanması sürecinde, TÜBİTAK proje bütçesinde kısıntıya gitmesine rağmen kendileri bütçeyi kısmamışlar ve ArGe faaliyetlerini yarım bırakmamışlardır. Bu teknoloji geliştirme stratejisi olarak önemli bir kazanımdır. Büyük bir güneş enerjisi tedarikçisi olan SolarTürk Enerji Şirketinde çalışan katılımcımız yine kendi bünyelerinde geliştirdikleri ve üç ortakla yürüttükleri bir projelerini olduğunu belirtmiştir. Öncesinde kendilerinin başladıkları ve TUBITAK desteğiyle de devam ettirdikleri proje ile, ürünlerini teknolojik olarak geliştirdiklerini ve hatta yerli tedarikçilerden hammadde (Şişecam'dan cam) desteği alarak yerli katkı payını artırdıklarını ve prototiplerini denemeyi sürdürdüklerini anlatmıştır. Uzun süredir teknoloji geliştirme faaliyeti yürüten ve $\% 100$ yerli türbin imal eden bir Türk firmasında çalışan katılımcımız, kendi teknoloji geliştirme faaliyetlerinde "pazar segmenti odaklı bir teknoloji geliştirme stratejisi" izleyerek büyük türbin yerine lisanssız pazar hedefli küçük türbinler ürettiklerini belirtmiştir. Lisanslı büyük pazar segmentinde ise yerli ürün üretmek için bireysel olarak değil konsorsiyumlar üzerinden çalışma yapmanın dünya pazarında teknolojik olarak rekabet edebilmek için Türkiye'nin gücünü artıracağını belirtmiş ve şöyle demiştir: "Teknolojiye sahip olan ve orta sınıf türbinler üreten firmaların, daha büyük ölçekteki sanayi firmaları ile bir araya gelerek oluşturacağı ortaklıklar ile büyük türbinler Türkiye'de üretilebilir ve dünya pazarında bu şekilde bir rekabetçi güç elde edebilir”. Katılımcımıza göre, bunun yolu tek başına gerçekleştirmek değil devlet politikaları ile desteklenmektir. Çünkü Ar-Ge riskli ve para kaybetme ihtimali olan bir faaliyettir ve olumlu ve olumsuz sonuçlardan yola çıkarak öğrenme süreci olarak da kurgulanmalıdır ve ancak aktif bir devlet politikası ile desteklendiğinde bu mümkündür. Başka bir katılımcımız tarafından güneş enerjisinde hücre geliştirmek için ortak aklın önemine vurgu yapılmış ve güçlü ve bütünlüklü bir desteğin önemi belirtilmiştir. $\mathrm{Bu}$ uzmanımıza göre sektörde "Ortak bir akıl, ortak bir yol haritası" ile kaliteli ve rekabetçi bir ürünün geliştirilmesi mümkün olacaktır ${ }^{\S \S}$. İlk güneş enerjisi lisanslarından birine sahip bir şirkette çalışan katılımcımız ise teknoloji geliştirme faaliyetlerinde olası pazarlara vurgu yapmış ve eğer geliştirilen teknolojinin pazarı hakkında kestirimde bulunmak zorsa, teknoloji geliştirme faaliyetinin de hedefinin net olamayacağını söylemiştir. Bunlar yerli firmaların teknoloji geliştirme stratejileridir ve Türkiye'deki pazarda teknoloji geliştirme açısından bu firmaların stratejileri ön plandadır. Yabancı menşeili tedarikçiler CSUN ve Alstom Şirketlerinde çalışan katılımcılarımız ise Türkiye'de teknoloji geliştirilmesine veya kendi teknoloji geliştirme faaliyetlerinin bir bölümünün Türkiye'de sürdürülmesine dair bir stratejileri olmadığını belirtmişlerdir.

Grup 2 temsilcilerine göre, yenilenebilir kaynaklara dayalı elektrik üretiminin yayılmasını destekleyen en önemli unsur, elektriği tüketenlerin aynı zamanda üretici olmasına imkan veren teknolojidir. Kamu kurumlarından birinde çalışan bürokrat

$\$ 2021$ yılında başlayan TFTP- Türkiye Fotovoltaik Teknoloji Geliştirme Platformu - TUBITAK 1004 Projesi bu doğrultuda yapılmış bir projedir ( detaylı bilgi için bknz: https://basinda.metu.edu.tr/icerik/odtuden/133/odtu-guname-ISSN: 2148-2683 uzmanımız, özellikle güneşte tüketim noktalarında üretme imkanınızın olduğunu, bu yolla dağıtım kayıplarının azaldığını ve bazı risklerin dağıtıldığını belirtmiş, aynı zamanda üreten tüketicinin üretim şebekesini ya da dağıtım şebekesini rahatsız etmeden ve onlara yük olmadan elektrik ihtiyacını karşıladığını söylemiştir. Bir diğer katılımcımız, Almanya'daki model City of Mannheim projesinden bahsetmiş ve özellikle üreten tüketici (prosumer) kavramından faydalanarak kurgulanan bu modelde farklı tarife saatlerindeki üretim ve tüketimi yönetme saikiyle enerjinin sürdürülebilir üretiminin ve verimli tüketiminin yaygınlaştırıldığını anlatmıştır. Ayrıca tüketicinin kendi elektriğini üretmesinin, onu daha bilinçli hareket etmeye yönlendirdiğini de vurgulamıştır. TEDAŞ’ta uzman olan katılımcımız, yenilenebilir enerji ile geleneksel şebeke planlamasının değiştiğini, önceden şebekenin tek yönlü olarak elektriği veren şebeke olarak planlandığını ama artık şebekenin aynı zamanda elektriği alan bir şekilde de kurgulanması gerektiğini söylemiştir. Bu durumda değişken üretim ve tüketimin şebeke üzerindeki etkilerini ve güç kalitesi problemini de iyi analiz etmek gerekliğinin ve yeni teknolojilerin, özellikle akıllı şebekenin, sisteme entegrasyonun kaçınılmaz olduğunu dile getirmiştir.

Grup 1 uzmanlarına göre, bu alanda en çok dile getirilen teknolojik engel sektördeki aktörlerde (özellikle teknik) bilginin eksikliğidir. Enerji danışmanlık şirketlerinden birinde çalışan katılımcımız, rüzgar enerjisinde olmasa bile güneşte henüz altını dolduramadığımız bir teknik ve teorik çalışma eksikliği olduğunu; dolayısıyla ilk aşamada bu açığın kapatılması gerektiğini söylemiş, güneş enerjisinde lisanslı pazarda 2013 yılında 600 MW gibi küçük bir miktar için açılan lisans başvurularının tamamlanmasının beklenenden uzun sürmesini, bu bilgi eksikliğine bağlamıştır. Enerji alanındaki yatırımcı şirketlerden birinde çalışan bir katılımcımız ise, yatırımcılarda da benzer bilgi eksikliğinin olduğunu belirtmiş ve ihaleyi kazanmış bir yatırımcıyı örnek vererek ihale şartlarını bile tam olarak bilmediklerini söylemiştir. Büyük ve alanında etkin bir danışmanlık şirketinde çalışan bir diğer uzmanımız, kendilerinin bir kamu kurumuna verdikleri hizmette, teknik şartnamedeki belli maddelerin maliyet artırıcı etkisini fark edip, işi tamamlarken bu maliyet unsurunu azaltmak istediklerinde (çelik konstrüksiyon yerine aynı işlevi görebilecek ve daha uygun maliyetle tamamlanabilecek alüminyum konstrüksiyonu önermişler), bunun kabul görmediğini, sebebinin de teknik bilgi eksikliği olduğunu söylemiştir. Dağıtım şirketlerinde de teknik altyapının o dönemde henüz tamamlanmadığını ve bu sebeple hala yenilenebilir kaynaklardan elektrik üretimi konusunda yavaş adımlar atıldığı da dile getirilmiştir. Rüzgar enerjisi alanında bir çok kuruluma destek vermiş bir danışman katılımcımız ise artık bu tür bilgi eksikliklerinin maliyetlerinin özellikle rüzgar enerjisinde çok ağır olduğunu ve yaptırımların çok artırıldığını, sürecin riski kaldırmayacak hale geldiğini söylemiştir. Üniversitede araştırmacı olarak görev yapan katılımcımız ise sırf bu bilgi eksikliğinden dolayı yaşanan absürt olaylar olduğunu belirtmiş ve 500 KWlık bir tesisi tamamlayan ve bağlantı iznini almayı atlayan bir yatırımcıdan bahsetmiştir.

Grup 2 uzmanlarına göre de teknik bilgi eksikliği önemli bir engel unsuru teşkil etmektedir. TEİAŞ çalışanı olan uzmanımıza göre, sektörde çok fazla bilgi sahibi olmadan hızlı bir şekilde karar verilmesi, baştan girilen yolun ne kadar sıkıntılı olduğunu bilmeden hareket edilmesinin bir sonucudur ve engelleri aşmada turkiye-fotovoltaik-teknolojileri-platformuna-tubitak-ardeb-1004mukemmeliyet-merkezi-destek-programi-yuksek-teknoloji-platformlari-cagrisidestegi) 
da problemler yaşanmasına sebep olmaktadır. Etkili bir sosyal medya kullanıcısı olan ve Türkiye'de güneş enerjisi alanındaki en etkin sosyal medya platformunu kuran uzman katılımcımız, bu sorunun kamuoyu açısından da çok yaygın olduğunu; yenilenebilir enerjide kamu oyunun teknik bilgisinin az, bilgi kirliliğinin de fazla olduğunu belirtmiştir. Bu sebeple kendi sosyal medya platformlarının çok ilgi gördüğünü ve takip edildiğini ve bu şekilde hızla ivmelenmesinin de tamamen talepten geldiğini söylemiştir. TEDAŞ çalışanı uzmanımız, bilgi eksikliğinin önceden çok daha vahim olduğunu, kendisine "güneşten elektrik mi elde ediliyor" diye bile sorulduğu dönemler olduğunu belirtmiş, son zamanlarda biraz daha farkındalığın arttığını ama yine de sektörün daha yolun çok başında olduğunu söylemiştir. EPDK'da uzman olarak çalışan katılımcımız ise, lisanslı başvurularda da benzer bir teknik bilgi eksikliğini işaret etmiş, örneğin rüzgar lisansına başvururken sahayı dahi görmeden başvuru yapanlar olduğunu söylemiştir.

\subsection{Siyasi Faktörler}

Siyasi faktörler ise, siyasi iradenin yenilenebilir enerji teknolojilerinin yayılması sürecinde doğrudan veya dolaylı yoldan oynadığı rolün etkilerini ifade etmektedir ve çalışmamızda 9 destekleyici, 3 engelleyici faktör belirlenmiştir (Tablo 7). Grup 1 'deki temsilcilere göre en s1k tekrarlanan destek "Devlet tarafından verilen teșvikler"dir, engel ise "Yasal Mevzuat Kapsamında alınan önlemler"dir. Grup 2'deki temsilciler ise aynı faktörleri en sık tekrarlamışlardır.

\section{Tablo 7. Siyasi Faktörler}

\begin{tabular}{l|l|c|c}
\hline & Faktör & $\begin{array}{l}\text { Grup 1: Özel sektör } \\
\text { kuruluşları (Kar amacı güden) }\end{array}$ & $\begin{array}{l}\text { Grup 2: Özel sektör } \\
\text { dışındaki kuruluşlar } \\
\text { (Doğrudan kar amacı } \\
\text { gütmeyen) }\end{array}$ \\
\hline Destekler & Devlet Teşvikleri & $\mathbf{1 7}$ & $\mathbf{5}$ \\
\hline & YE teknolojilerine finansal destekler & 7 & 2 \\
\hline & İthalata bağımlılı̆̆ı azalması & 6 & 2 \\
\hline & Enerji sepeti etkisi & 5 & 0 \\
\hline & Ülke deneyimleri & 5 & 5 \\
\hline & Enerji arz güvenliği & 2 & 3 \\
\hline & Diğer YE kaynaklarındaki destekler & 2 & 0 \\
\hline & Yatırım için doğrudan destek & 1 & 1 \\
\hline & Kırsal kalkınma & 1 & $\mathbf{1 1}$ \\
\hline Engeller & Mevzuat Kapsamında alınan önlemler & $\mathbf{1 5}$ & 2 \\
\hline & Şeffaflık & 6 & 4 \\
\hline & Teknoloji geliştirme vizyonundan & 3 & 1 \\
\hline
\end{tabular}

Grup 1 temsilcileri için devlet tarafından verilen teşvikler, özellikle güneş enerjisi santrallerini çok karlı yatırımlar haline getirmiştir. Lisanslı güneş enerjisi alanında ilk lisansı alan şirketlerden birinde çalışan katılımcımız kendi sözleriyle bu çalışma yapıldığı dönem olan 2014-2015 yılları arasında yürürlükte olan devlet teşvikinin avantajlarını şu şekilde anlatmıştır:

"Kurmuş olduğunuz bu santral size MW ölçeğinde 1 milyon avroya mal oluyor. Yılda ortalama $1600 \mathrm{MWs}$ enerji üretiyorsunuz. Onu da teşvik fiyatlarıyla (KWs başına 13,3 dolar sent) çarptığınızda 7 yılda kendisini ödüyor. 7 yılda dolar bazında kendisini ödeyen demek, dolar bazında size yılda yüzde 13 faiz getiriyor demektir. Var mı böyle bir şey? Acayip karlı. Dolar bazında kim kime yüzde 13-14 faiz veriyor? Demek ki şu an güneş için verilen feed in tariff (parasal teşvik) yüksek."

Grup 2'den bir diğer uzman ise, devletin Avrupa Birliği uyum süreçlerinde enerjinin ciddi bir kısmını yenilenebilir enerji kaynaklarından elde etme hedefi olduğundan 13,3 dolar sent gibi iyi bir teşvik miktarı belirlediğini ve sektörün bundan çok faydalandığını belirtmiştir. Danışman katılımcılarımızdan biri, teşvik miktarlarından dolayı özellikle sanayide lisanssız kurulumların çok avantajlı hale geldiğini vurgulamıştır. Sanayinin kilovatsaat başına 20 kuruşa elektrik kullandığını ama devletin 33-34 kuruştan ${ }^{* * *}$ üretilen güneş elektriğini satın aldığını; yani fabrikaların çatısında elektrik üreterek kullanmadığı fazla elektriği şebekeye satmasının çok karlı bir yatırım olduğunu söylemiştir. Bu örnekte olduğu gibi özellikle sanayi kuruluşları için lisanssız çatı uygulamaları teşviklerden dolayı karlı yatırımlar haline gelmektedir. Fakat yerli üretimin teşviklerle desteklenmesi konusunda aynı karlılık oranları geçerli değildir ve yerli ürün tedarikçileri bundan şikayet etmektedir. Yerli üretime verilen teşvik dolaylıdır ve yerli ürün kullanan elektrik üreticilerinin elektrik satın alma fiyatlarının 13,3 UScent/kWs'den (en fazla) 20 UScent/kWs' çıkarılarak yerli ürün kullanımı teşvik edilmektedir. Fakat yerli üretim doğrudan desteklenmemektedir. Elektrik üreticisi ve danışman olan iki katılımcımız bu konuyu gündeme getirmişler, kendileri de birer yerli teknoloji üreticisi olan iki tedarikçi uzmanımız ise kendi deneyimlerinden yola çıkarak doğrudan yöntemi eleştirmişler ve çok fayda göremediklerini belirtmişlerdir. Yerli türbin üreten

\footnotetext{
**** C18 mülakat sırasinda ogünkü dolar kuruyla 13,3 dolar sentin TL karşılığını hesaplamış ve 33-34 kuruşa denk geldiğini söylemiştir. 
tedarikçi uzmanımız bunun temel nedenin teşviklerin bir ekonomik model kapsamında verilememesi olduğunu belirtmiş ve şöyle demiştir:

"Bence bir ekonomik model sübvansiyonla ayakta duruyorsa bu zaten ekonomik model değildir, mecburiyeti vardır devletin, elektrik talebinin karşılanması gerekiyordur, yapar. Ama bir makine yapıldığında, o ülke şartlarında oranın ekonomik modeli içerisinde kendisine özgü olursa, o zaman zaten göğsünüzü gere gere benim böyle yerli bir malım var, ben bunu satıyorum ve bu mal iş yapıyor dersiniz. Yoksa 20 senede ödüyor makinam kendini ama devlet bana \%20 hibe verirse 10 seneye düşüyor bu gibi bir söylem ekonomik model değildir. Liberal ekonomiye yani serbest yatırıma yakışmaz"

Grup 2 temsilcileri de devlet teşviklerini en önemli siyasi destek olarak tanımlamıştır. Düzenleme faaliyeti yapan bir katılımcımız, yenilenebilir enerji kaynaklarını desteklemek için sadece teşvik mekanizması değil bu kaynaklara özel yöntemler de uyguladıklarını belirtmiştir. Örneğin elektrik şebekesine üretip satmayı planladıkları miktarı doğa koşullarındaki aksaklıklar (rüzgarın esmemesi gibi) olduğunda ve dengesizlik pozisyonuna düştüklerinde, diğer kaynaklar için tanınmayan bir hak yenilenebilir kaynaklara tanınmış, bu elektriği dışardan temin edip yani ticaret yoluyla alıp satabilmeleri için düzenleme yapılmıştır (normalde elektrik üretim tesislerinin ticaret yapma hakk1 yoktur). Bir diğer düzenlemeden sorumlu bürokrat katılımcımız, YEKDEM (Yenilenebilir Enerji Kaynakları Destekleme Mekanizması) ${ }^{\dagger \dagger}$ den faydalanan yatırımcı sayısının oldukça fazla olduğunu, özellikle rüzgâr enerjisindeki sayının son zamanlarda oldukça arttığını belirtmiştir. Özellikle YEKDEM mekanizmasında kanunda yapılan bir değişiklik ile önceden \%80 olan YEKDEM'e başvurmak icin gerekli yerli katkı oranının $\% 55$ e düşürüldüğünü ve böylece başvuran sayısının daha da arttığını söylemiştir.

Grup 1'de yer alan temsilcilere göre en büyük siyasi engel, mevzuatla belirlenmiş önlem mahiyetindeki zorunlu uygulamalardır. Bu uygulamalardan en çok dile getirilen ölçüm zorunluluğudur. Mevzuat gereği, rüzgar ve güneş enerjisine dayalı elektik üretim lisansları başvuruları ile birlikte, başvurulan bölge için 6 ay yerinde toplamda 1 ylllık bir ölçüm bilgisinin sunulması zorunludur. Fakat bu zorunluluk özellikle yatırımcılar açısından büyük bir külfet ve anlamsız bir zorunluluk olarak algılanmaktadır. Bir elektrik üreticisi, güneş santrallerinde ölçüm zorunluluğu ve rüzgar santralleri için bölgedeki radar faaliyetlerine etkilerinin incelenmesinin yatırımcıyı maliyet, süre ve iş gücü açısından fazladan yorduğunu; eğer gerekli görülüyorsa başka yöntemlerle de ölçümün yapılabileceğini belirtmiştir. Danışman bir katılımcımız ise, güneş enerjisinde 6 aylık yerinde ölçümün aslında yeterli olamayabileceğini, aslında bu verilerin Meteoroloji Genel Müdürlüğü'nden alınmasının daha sağlıklı olduğunu söylemiştir. Öte yandan ölçüm zorunluluğunun yeterli yatırım koşulu olamayacağı belirtilmiştir. Çünkü kendisine göre, direk dikmek maddi güçle alakalıdır ve cebinde parası olan her yatırımcı direk dikip ölçüm yapabilir ama sonradan bu ölçümü veya sahayı düzgün değerlendirip verimli bir yatırıma

†† YEKDEM'de yer alan tesislere uygulanacak fiyatlar YEK Kanunu ile belirlenmiş olup güneş enerjisine dayalı üretim tesisleri için ise 13,3 UScent $/ \mathrm{kWs}$ şeklindedir. Üretim tesisinde yerli aksam kullanılması ve ilgili yerli aksamın "Yenilenebilir Enerji Kaynaklarından Elektrik Enerjisi Üreten Tesislerde Kullanılan Aksamın Yurt İçinde İmalatı Hakkında Yönetmelikte Değişiklik Yapılmasına Dair Yönetmelik" e-ISSN: 2148-2683 çevirememe ihtimali vardır. Elektrik üreticisi bir katılımcımız ise, lisanslı güneş enerjisi başvurularında ölçüm zorunluluğun bir politika yanlışlı̆̆ı olduğunu söylemiş, başvuru sahibi her potansiyel yatırımcının diktiği direklerden alınan verilerin sağlıklı olmayacağını düşündüğünü iletmiştir. Güneş enerjisinde her biri 20.000 avro civarı olan bu direklerin çok gereksiz bir de masraf yarattığından şikayet edilmiştir. Danışman olan bu temsilcimiz, örnekle açıklamış ve bir direğin ortalama 20 bin avro olduğu varsayılırsa, 2015'teki başvurular için 1300 tane direk dikilmiş olduğunu bildiğini ve toplam miktarın yaklaşık 30 milyon avro olduğunu hesaplamış, bunun en fazla 10 milyon avrosu Türkiye'de kalsa, 10 milyon avronun yurtdışına gittiğini, yani yaklaşık 10 MWlık bir santralin parasının ölçüm için heba edildiğini belirtmiştir.

Grup 2 temsilcilerine göre de en büyük siyasi engel ölçüm zorunluluğudur. Meteroloji Genel Müdürlüğü'nde çalışan katılımcımız, ölçüm zorunluluğunun aslında iyi bir uygulama olduğunu ve gerekli olduğunu, güneş enerjisi başvuruları alınırken veri eksikliğinden veya yanlışlığından kaynaklanabilecek sorunları engellemek için mutlaka yapılması gerektiğini söylemiştir. Ama "vur dedik öldürdüler" diye de eklemiştir. Çünkü bu yöntemle herkesten veri toplanmasının çok sağlıklı sonuçlar doğurmadığını belirtmiştir. Kural bu şekilde belirlendiği için her ölçüm direğinden Meteoroloji Genel Müdürlüğü'ne veri gittiğini ve hangisinin ne kadar sağlam kaynaklar olduğunun bilinmediğini, alınan verinin de düzgün işlenemediğini belirtmiştir. Akademisyen olan katılımcılarımızdan biri ise, ölçümün profesyonelce yapılmasının zorunlu ve ciddi bir iş olduğunu ve herkes tarafından gelişi güzel yapılamayacağını belirterek işin teknik kısmına vurgu yapmıştır. Zaten güneş enerjisinde birçok veri kaynağından (NASA'nın verileri, Avrupa Birliği verileri, üniversitelerin yaptığı çalışmalar gibi) bölgesel potansiyele dair bilgi edinilebileceğini söylemiş ve bir şeyi doğru olarak ölçmenin ciddi bir uzmanlık gerektirdiğini vurgulamıştır. Bu sebeple ölçüm zorunluğunu doğru bulmadığını dile getirmiştir. Bürokrat katılımcılarımız ise, aslında ciddi olan gerçek yatırımcının zorunluluk olmadan da bu ölçümlerini yapacaklarını söylemişler, özellikle finansal kaynak bulmak istediklerinde bankaların bu ölçümleri mutlaka görmek istediklerini belirtmişlerdir. Bir danışman katılımcımızın ise ölçüm yapılma metodu hakkında bir eleştirisi olmuş ve başvuru yapan herkesten ölçüm verisi istemek yerine başvurular değerlendirildikten ve yarışmalar yapıldıktan sonra ölçümü asıl yatırımcının yapmasının daha anlamlı olacağını; başvuru öncesinde ise profesyonel olarak tek elden yapılmış ölçüm verilerinin kullanılmasının anlamlı olduğunu belirtmiştir.

\subsection{Yönetimsel Faktörler}

Yönetimsel faktörler ise, yenilenebilir enerji teknolojisinin yayılması sürecinin yönetimi ile ilgili etkileri kapsamaktadır ve çalışmamızda 2 destekleyici, 10 engelleyici faktör belirlenmiştir (Tablo 8). Grup 1 temsilcilerine göre en sık söylenen destekleyici faktör yenilenebilir enerji teknolojilerinin kullanılmaya başlanmasının "Puant Azaltma Etkisi"dir, engelleyici faktör ise "Bürokrasi"dir. Grup 2 için ise, en sık tekrarlanan yönetimsel

hükümleri ve diğer ilgili mevzuat kapsamında belgelenmesi halinde ise bu fiyatlara yine YEK Kanunu Ek-II sayilı

cetvelinde yer alan fiyatlardan beş yıl süreyle ilave edilir. Bu miktar ise en fazla 20 UScent/kWse çıkmaktadır.

(http://www.epdk.org.tr/index.php/elektrik-piyasasi/yekdem) 
destek, "Kayıp kaçak oranını azaltıcı etki"dir. Olumsuz etkileyen yönetimsel faktör ise "Yarışma Süreci"dir.

Tablo 8. Yönetimsel Faktörler

\begin{tabular}{l|l|c|c}
\hline & Faktör & $\begin{array}{l}\text { Grup 1: Özel sektör } \\
\text { kuruluşları (Kar amacı } \\
\text { güden) }\end{array}$ & $\begin{array}{l}\text { Grup 2: Özel sektör } \\
\text { dişındaki kuruluşlar } \\
\text { (Doğrudan kar amacı } \\
\text { gütmeyen) }\end{array}$ \\
\hline Destekler & Puant azaltma Etkisi & $\mathbf{2}$ & 0 \\
\hline & İletim Kayıplarının azalması & 1 & $\mathbf{1}$ \\
\hline Engeller & Bürokrasi & $\mathbf{4 0}$ & 12 \\
\hline & Kurulum plan ve izinleri & 15 & 4 \\
\hline & Arazi sorunları & 11 & 12 \\
\hline & Farklı YE Kaynaklarındaki olumsuz deneyim & 10 & 10 \\
\hline & Değişen kurallar & 7 & 2 \\
\hline & Lisans Yarışmaları & 9 & $\mathbf{1 5}$ \\
\hline & Öztüketim zorunluluğu & 4 & 0 \\
\hline & Başvuru sürecindeki sorunlar & 3 & 0 \\
\hline
\end{tabular}

Grup 1, puant azaltma etkisini en s1k dile getirmiştir. Özellikle tüketimin fazla olduğu ve kaynağın da bol olduğu yazın gündüz saatleri gibi zamanlarda şebekenin beslenmesini ve puant artışının dengelenmesini sağlayacağı için yenilenebilir enerjinin ve özellikle gündüz puantları için güneş enerjisinin çok avantajlı olduğu belirtilmiştir. Elektrik piyasasında elektrik fiyatlandırmasının puant yük değerine göre yapıldığını bildiğimiz için, puant düştüğü sürece maliyetlerin de düşeceği, böylece elektrik fiyatlarının da azalacağını söylenmiştir. Elektrik üreticisi bir katılımcımız, yenilenebilir enerji ne kadar fazla olursa o kadar az enerji kısıtımız olacağını ve puant değerlerimiz de o kadar azalacağı için, özellikle güneşin en bol olduğu ve elektrik tüketimimizin en fazla olduğu öğle saatlerinde piyasadaki volatilitenin de azaltmış olacağını belirtmiştir.

Grup 2 uzmanlarımıza göre yenilenebilir enerji teknolojilerinin yayılmasını en olumlu etkileyen yönetimsel faktör, kayıp kaçak oranının azalmasıdır. Bu konuyu düzenleme ile görevli bir bürokrat katılımıımız dile getirmiş ve özellikle doğu bölgelerinde sorun olan kaçak elektrik kullanımının ve santrallerden uzak bölgelerde konumlanan ve bu mesafeden dolayı iletim hatlarında olabilecek kayıpları engellemek için yerinde ve yenilenebilir kaynaklarla yapılacak üretimi çok önemsediklerini ve teknoloji geliştirme faaliyetlerini buna göre desteklediklerini belirtmiştir.

Grup 2 temsilcileri en sık bürokrasi temelli engelleri yönetimsel engel olarak dile getirmişlerdir. Görüşülen uzmanlar hem lisanslı hem de lisanssız pazar segmentlerinde karşımıza çıkan bürokratik engelleri değerlendirmişler ve özellikle lisanssız elektrik üretimi alanında prosedürlerin çok fazla olmasından ve bu prosedürlerin lisanssız kurulumları çok zorlaştırmasından yakınmışlardır. Özellikle lisanssız kurulumlarda teknik konuların ve tedbirlerin değil şekille ilgili kısımların çok ön plana çıktığından söz edilmiş ve sektördeki paydaşların bu yüzden kağıt evrak işinde enerjilerini gereksiz yere harcadıkları söylenmiştir. Danışman bir katılımcımız, yine lisanssız elektrik üretimindeki bürokratik engellerden bahsetmiş ve bireylerin kendi çatısına kuracağı doğrudan üretildiği yerde tüketilecek enerjinin kolay bir şekilde şebekeye entegre edilmesi için idari süreçlerin kolaylaştırılmasını önermiştir. Örneğin danışmanlık şirketi çalışanı bir diğer katılımcımız çatılarında güneş enerjisi sistemi e-ISSN: 2148-2683 olduğunu ama çalıştıramadıklarını söylemiştir. Elektrik üreticisi bir katılımcımıza göre, lisanssız santral başvuru sürecinde bürokrasi ağır işlemekte ama başvuru kabul edildikten sonra da süreç sadeleşmemektedir. Çalışmanın yapıldı̆̆ı dönemde, bu katılımcımız başvuru kabulünü yaptırabilmek için bir ay uğraşmanın gerektiğini ve nerdeyse tesis kadar para harcandığını, sonrasında da çatının statiği, itfaiye izni, "ÇED gerekli değildir" belgesi gibi bir çok ek adımı tamamlamak gerektiğini, kurulan 3,5 Kwlık tesis için bu kadar enerji ve zaman harcandığını anlatmıştır. Danışmanlık yapan başka bir şirket temsilcisi ise yine lisanssız elektrik üretimindeki zorluklara dikkat çekmiş, çatıda güneş enerjisinden su ısıtmanın izne tabi olmadığını ama izinsiz elektrik üretilemediğini, hatta 17 farklı kurumdan izin almanız gerektiğini ve bunun 1 yıl da sürebileceğini söylemiştir. Yerli panel tedarikçisi katılımcımız ise izin süreçlerinin bu kadar uzun sürmesinin kendi büyüme hedefleri olan yıllık $50 \mathrm{MW}$ panel satış hedeflerine ulaşmalarını güçleştirdiğini belirtmiştir.

Lisanslı santral başvuruları için de benzer bürokratik engeller gündemdedir. Elektrik üreticisi bir katılımcımız, yenilenebilir enerji kaynaklarına dayalı elektrik üretiminde 2005ten sonra mevzuatla birlikte bir sistem oturtulmaya çalışıldığını ama bürokrasinin buna ayak uyduramadığını söylemiştir. Güneş enerjisi lisansına sahip katılımcımıza göre, bürokrasiden beklenen "bu sistemin sağlıklı işlemesi, sağlıklı gelişmesi ve olgunlaşması için prosedürlerin geliştirilmesi, yetkilerin doğru düzgün dağıtılması, bununla ilgili karar vericilerin eğitilmesi, merkeziyetçi başlayan bu sistemin ademi merkeziyetçi bir yapıya kavuşması için atılması gereken adımların atılması"ydı ama bu yapılamamıştır.

Bir diğer güneş enerjisi lisans sahibi katılımcımız, bürokratik engellerin lisanslı elektrik üretimi konusunda aksaklıklara neden olduğunu belirtmiştir. Kendilerinin 2012'nin kasımında güneş enerjisine yatırım yapma kararını net şekilde aldığını ve 2014 kasımına gelindiğinde hala önlerinde en az dokuz aylık bir süreç daha olduğunu söylemiş ve bu zamanın sadece yatırıma başlayabilmek adına geçtiğini belirtmiştir. Bu katılımcımız, 3 yılda 7 MWlık basit bir güneş enerjisi santralini, kurabilme kararını netleştirebilmenin bu kadar zaman alıcı ve ağır işleyen bir süreç olduğunu, bu durumdaki bir yatırımc1 4,5 yılda bir güneş santrali projesi geliştiriyorsa, onun yerine bir yılda doğalgaz 
santrali yapmayı tercih etmesinin anlaşılabilir olacağını belirtmiştir. Lisanslama sürecinde mevzuatı oturtmanın da bir yandan çok zaman aldığ 1 ve yaklaşık 4-5 sene firmaların mevzuat otursun diye beklendiği dile getirilmiş ama buradaki asıl bekleyenin firmalar değil, ülkenin enerji ihtiyacı olduğundan yakınılmıştır. Danışmanlık faaliyeti yürüten bir karılımcımız ise bürokrasinin yavaş işlemesinin bir sebebinin de sorumlu kurumlardaki uzmanların sayıca az olmasından ve görev dağılımını yapamamalarından kaynaklandığını söylemiştir. Örneğin lisanssız tesis kabullerin yapılmasında TEDAŞ’tan uzmanların sahada incelemeye gittiğini, ama bu inceleme sorumluluğunun (kurulum gücünde üst limit olmaksızın) TEDAŞ'ın bölge temsilciliklerine bırakılmasının gerekliliğini vurgulamıştır ${ }^{+*}$.

Elektrik üretici bir katılımcımız ise bürokrasiyi, devlet bir yandan büyük duble yollar açarken öbür taraftan ilerde yola radar koyup ve hız sınırını $50 \mathrm{~km} /$ saat olarak belirlemesine benzetmiştir ve bunu aslında devletin bilinçli bir tercih olarak yaptığını söylemiştir. Bir diğer danışman katılımcımıza göre ise bürokrasiyi azaltmak bürokrattan değil, kanunu yapan meclisten beklemelidir ve bunun için de siyasi kanallardan baskı yapmanın iyi olacağını, sürekli bürokratları eleştirmenin anlamlı olmadığını çünkü onların da kendi işlerini yapmaya çalışan uzman ve eğitimli insanlar olduğunu söylemiştir.

Grup 2'de yer alan katılımcılarımız tarafından en sık dile getirilen engelleyici yönetimsel faktör lisanslı elektrik üretim santrali lisansını almayan hak kazanan başvuru sahibinin belirlenmesi için; başvuranlar arasında yapılan yarışma sürecidir. Güneş ve rüzgar enerjisine dayalı lisanslı elektrik üretim tesisi kurulumlarında belli dönemlerde belli bölge ve kapasitelerde ${ }^{\S \S}$ tesis kurulması için başvuru alınmaktadır. Güneş enerjisine dayalı elektrik tesisleri için aynı bölgede birden fazla başvuru olması durumunda lisans sahibini belirmek için katkı payı (1 MW kurulum bedeli için devlete ödenecek miktar) üzerinden yarışma düzenlenmektedir ve en fazla katkı payını ödemeyi taahhüt eden başvuru sahibi yarışmayı kazanmaktadır. Fakat Grup 2'de yer alan katılımcılarımıza göre yarışma mantığı yenilenebilir enerji kaynaklarına dayalı elektrik üretim teknolojilerinin yayılmasını engelleyen yönetimsel bir faktördür. Düzenleme alanında çalışan bir katılımcımız, kapasiteleri (yani şebekeye bağlanabilme hakkını) bu şekilde kapalı tutup sadece belli bir zaman diliminde açmanın aslında bir imtiyaz dağıtmak anlamına geldiğini söylemiştir. Bu durumda gerçek yatırımcı dışında başkalarının da o imtiyazı almasının ve sonrasında bu imtiyazı ikinci el bir piyasa oluşturup orda satmak üzere kullanmasının mümkün olduğunu belirtmiş; bunun da gerçek yatırımcının önünü kesebileceğini söylemiştir. Dolayısıyla gerek rüzgarda gerek güneşte lisanslı projelerin başvuru ve lisanslama süreçlerini yeniden ele almak gerekmektedir ve lisanslı elektrik üretim tesislerinin kurulmasında ön lisans başvurularının her zaman açık olduğu bir mekanizmaya gidilmesi önerilmiştir. Güneş enerjisi ile ilgili bir derneği temsilen çalışmamıza katılan bir uzmanımız, diğer enerji kaynaklarından örnek vermiş ve Türkiye'de bir doğal gaz santrali veya bir kömür santrali yapmak istediğinizde ihale sürecine tabi olmadığınızı ama güneş ve rüzgar santrali yapmak istediğinizde bir ihale sistemi olduğunu belirtmiştir. Yenilenebilir enerji santrali

\#+2014 Şubat itibarıyla Lisanssız Elektrik Üretimine İlişkin

Yönetmelik" kapsamında kurulu gücü $11 \mathrm{kWe}(11 \mathrm{kWe}$ dahil) ve altındaki Güneş Enerjisine Dayalı (GES) santrallerin proje onay ve kabul işlemleri için TEDAŞ Bölge

Koordinatörlükleri görevlendirilmiştir (Kaynak:

http://www.tedas.gov.tr/KitaplikDuyuruDokumanlar/11kWe_alti_GES_

Projelerinin_YetkiDevri_\%20duyurusu.pdf)

e-ISSN: $2 \overline{1} 48-2683$ kurmak istediğinde uygun bir bölge bulan ve orada ölçümlerini yapan bir yatırımcının devlet tarafından bir nevi engellenerek yarışmaya tabi tutulmasının anlamsız olduğu belirtilmiş; o araziyi önceden bulanın bir avantajı olması gerektiğini ve devletin, eğer o yatırımcının verdiği katkı payı miktarını beğenmezse yarışma yoluna gitmesi önerilmiştir. Düzenleme kurumunda çalışan bir katılımcımız ise yarışmaların bölge bölge belirlenmesini ve her bölgeye belli kapasitelerin açılmasını eleştirmiştir. Kendisine göre tüm illerde kapasite belirlemek çok da anlamlı sonuçlar doğurmayabilecektir. Çünkü mukayeseli üstünlükler gözetilerek her il hangi konuda üstünse ona göre çalışma yapmak gerekir. Güneş enerjisine dayalı tesislerin lisans başvurularında olduğu gibi, bölgelerin mukayeseli üstünlükleri gözetilmeden kapasite açıklanması, kendilerinin yarışma süreçlerini yürütmelerinde zorluklara neden olmuştur. Danışman olan bir katılımcımız ise yarışmaları kazanmak için başvuru sahiplerinin katkı payı miktarlarını çok arttırdıklarını ve bunun da ek maliyet getiren bir unsur olduğu için tesislerin kurulmasını engelleyebileceğini söylemiştir. MW başına 2,5 milyon TL'ye varan katkı payları olduğunu söylemiş, bu katkı payı miktarının çok yüksek olduğunu ve yatırımların geri dönüş sürelerini çok uzatabileceğini belirtmiştir. $\mathrm{Bu}$ tip bir hareket tarzının ekonomik temellerden ziyade psikolojik temelleri olduğunu düşündüğünü, gelişmekte olan bu sektörde söz sahibi olan ilk aktörlerden biri olmak için bu şekilde teklifler verilmiş olabileceğini belirtmiştir. Fakat bu durumun tesislerin kurulmasını engelleyebileceğinden tedirgin olduğunu söylemiştir. TEİAŞ çalışanı olan katılımcımız ise yarışma sürecinin aslında 2007 döneminde rüzgar santralleri için yapılan lisans başvurularında sorun olan çok sayıda başvuru arasında, güçlü olmayan başvuruları elemek için geliştirilen bir çözüm yöntemi olduğunu söylemiştir. Hasılı yarışma süreci spesifik bir problemi çözmek için geliştirilmiş spesifik bir çözüm olarak kurgulanmıştır. Fakat o spesifik çözümün sonradan genel bir yöntemmiş gibi algılanmasını çok doğru bulmadığını, dünyanın başka ülkesinde benzer bir şekilde başvuruları alıp yarıştıran bir mekanizma olmadığını söylemiştir. Bu sebeple yarışma sürecinin fazladan bir zorluk yarattığını da eklemiştir,

\section{Sonuç}

Mevcut çalışmada rüzgar ve güneş enerjisi örnekleri bağlamında yenilenebilir enerji teknolojilerinin yayılmasını engelleyen ve destekleyen faktörlerin neler olduğu araştırılmış ve sonuçlar kar amacı güden kuruluşlar (Grup 1) ve kar amacı gütmeyen kuruluşlar (Grup 2) üzerinden sunulmuştur. $\mathrm{Bu}$ faktörler ekonomik, fiziksel, kurumsal, psikolojik, teknolojik, siyasi ve yönetimsel olmak üzere kendi içlerinde yedi ayrı başlık altında gruplanmıştır.

Kar amacı güden ve doğrudan kar amacı gütmeyen kuruluş temsilcileri açısından bir değerlendirme yapıldığında kar amacı güden kuruluş temsilcilerine göre kurumsal faktörler, siyasi faktörler ve yönetimsel faktörler belirleyici iken; doğrudan kar amacı gütmeyen kuruluş temsilcilerine göre ise daha çok ekonomik faktörlerin belirleyici olduğu görülmektedir.

$\S \S \S$ Örneğin 11-14 Haziran 2013 tarihleri arasında 27 ayrı bölgede yapılacak ve toplam kapasiteleri $600 \mathrm{MW}$ olan güneş enerjisine dayalı elektrik üretimi tesisinin lisans sahiplerini belirlemek için başvuru alınmış ve çoklu başvuru yapılan bölgeler için Mayıs 2015e kadar yarışmalar düzenlenmiştir. 
Kar amacı güden kuruluşlar açısından ekonomik faktörler arasında en çok dile getirilen destekleyici unsurlar maliyet açısından rekabet edebilme, istekli yatırımcıların varlığı, artan elektrik tüketimi, yüksek elektrik fiyatları, yeni yatırım olanakları olurken; engelleyici faktörler piyasa oluşumundaki aksaklıklar, yüksek kurulum maliyetleri, yüksek depolama maliyetleri, finansal model olmaması, uzun geri dönüş süreleri ve proje finansman eksikliği olarak sıralanmıştır. Kurumsal faktörler arasındaki destekleyici mekanizmalar, kilit uzmanlarla işbirliği yapma, olumlu lobi ve savunma grubu, işbirliği ve ağ yapıları, yenilenebilir enerji kaynaklarına öncelik tanınması, dünyada yenilenebilir enerji kaynaklarına artan ilgi olarak tespit edilmiş; kurumsal engeller ise işbirliğinde sorunlar, kamu kurumları arasında koordinasyon olmaması, karşı lobilerin olması, yeni teknolojiye uyumda sorunlar, kritik kütlenin olmaması ve ağ yapısındaki sorunlar olarak belirlenmiştir. Yönetimsel faktörler ve siyasi faktörler içindeki destekleyici faktörler ithalata bağımlılığın düşmesi, diğer ülke örneklerinden çıkarılan dersler, yatırımlar için sağlanan destekler ve devlet teşvikleri olurken; engelleyici faktörler teknoloji geliştirme vizyonun olmaması, yasal mevzuat kapsamında alınan önlemler, şeffaflık olmaması, bürokrasi, sürekli değișen kurallar ve arazi sorunları olarak tespit edilmiştir.

Kar amacı gütmeyen kuruluşlar açısından ise engelleyici ve destekleyici faktörler arasında en fazla öne çıkanlar, maliyet ve yatırım kaynaklı mekanizmalar, destekler ve engeller bağlamında değerlendirilen ekonomik faktörler olmuştur. Yenilenebilir enerji teknolojilerinin getirdiği yeni yatırım olanakları ve maliyet açısından rekabet edebilme doğrudan ifade edilen destekleyici faktörler iken, yüksek başlangıç yatırımı maliyetleri en çok engelleyici faktör

\section{Kaynakça}

Bergek, A., Jacobsson S., Carlsson B., Lindmark S., Rickne A. (2008). Analyzing the functional dynamics of technological innovation systems: A scheme of analysis. Research Policy, $37,407-429$

Bektaş ( 2013). Binalarda Rüzgar Enerjisi Kullanımının Farklı Bölgeler Açısından Değerlendirilmesine Yönelik Bir Çalışma : Toki Tarımköy Projesi Örneği, İstanbul Teknik Üniversitesi. Basılmamış Yüksek Lisans Tezi.

Corbin, J., A, Strauss (2008). Basics of qualitative research (3. Basım). Kaliforniya: Sage.

Dewald, U., Truffer B. (2011). Market Formation in Technological Innovation Systems-Diffusion of Photovoltaic Applications in Germany", Industry and Innovation, 18 (3), 285-300

Enerji ve Tabii Kaynaklar Bakanlığı (2005). Yenilenebilir Enerji Kaynaklarının Elektrik Enerjisi Üretimi Amaçlı Kullanımına İlişkin Kanun, 18/5/2005 tarihli 5346 sayılı. https://www.mevzuat.gov.tr/MevzuatMetin/1.5.5346.pdf (Erişim Tarihi: 15.08.2021)

Enerji ve Tabii Kaynaklar Bakanlığı (2019). TC Enerji ve Tabii Kaynaklar Bakanlığ $2019-2023$ Stratejik Planı. https://sp.enerji.gov.tr/ETKB 20192023 Stratejik_Plani.pd $\underline{\text { f (Erişim Tarihi: } 29.05 .21)}$

Emeksiz, C., \& Fındık, M. M. (2021). Sürdürülebilir Kalkınma İçin Yenilenebilir Enerji Kaynaklarının Türkiye Ölçeğinde Değerlendirilmesi. Avrupa Bilim ve Teknoloji Dergisi, (26), 155-164. 10.31590/ejosat.948729

Flyvbjerg, B. (2006). Five Misunderstandings about Case-Study Research. Qualitative Inquiry, 12 (2), 219-245.
Gan, L., Eskeland G. S., Kolshus H.H. (2007). Green electricity market development: Lessons from Europe and the US, Energy Policy, 35, 144-155

Huang, Y. H., Wu J. (2009). A transition toward a market expansion phase : Policies for promoting wind power in Taiwan, Energy, 34, 437-447

Jacobsson, S., Bergek, A. (2004). Transforming the energy sector: The evolution of TIS in renewable energy technologies, Industrial and Corporate Change, 13 (5), 815-849

Jacobsson, S., Lauber, V. (2006). The politics and policy of energy system transformation-explaining the German diffusion of renewable energy technology. Energy Policy, 34, 256-276

Karagöl, E. T., \& Kavaz, İ. (2017). Dünyada ve Türkiye'de yenilenebilir enerji. Analiz. Seta, 197, 18-28.

Kayar, E., Niyazi, İ. L., \& CARLAK, H. (2021). Türkiye Elektrik Enerjisi Görünümü ve Yenilenebilir Enerjinin Global Ölçekte Mevcut Konumu. EMO Bilimsel Dergi, 70-83.

Kemp,R. Schot, J., \& Hoogma, R. (1998). Regime shifts to sustainability through processes of niche formation: The approach of strategic niche management. Technology Analysis \& Strategic Management, 10:2, 175-198

Marinova, D., Balaguer, A. (2009). Transformation in the photovoltaic industry in Australia, Germany and Japan: Comparison of actors, knowledge, institutions and markets. Renewable Energy, 34, 461-464

Musiolik, J., Markard, J. (2011). Creating and shaping innovation systems: Formal networks in the innovation system for stationary fuel cells in Germany. Energy Policy, 39, 19091922

Patton, M.Q. (2002). Qualitative Research \& Evaluation Methods. (3. Baskl). California: Sage

Tsoutsos, T. D \& Stamboulis, Y. A. (2005). The sustainable diffusion of renewable energy technologies as an example of an innovation-focused policy. Technovation, 25 (7), 753-761.

Türkiye Petrolleri (2020). Petrol ve Doğalgaz Sektör Raporu. https://www.tpao.gov.tr/file/2106/2020-petrol-ve-dogal-gazsektor-raporu-47460b743c70c609.pdf (Erişim tarihi: 23.11.2021)

Türkiye Cumhuriyeti Dişişleri Bakanlığı. (2021). https://www.mfa.gov.tr/turkiye_nin-enerjistrateji.tr.mfa (Erişim tarihi: 23.11.2021)

Türkiye Elektrik İletim A.Ş. (2021). Santral Kurulu Güç Raporlar1. https://www.teias.gov.tr/tr-TR/kurulu-gucraporlari (Erişim tarihi: 23.11.2021)

Weber, K. M., Rohracher H. (2012). Legitimizing research, technology and innovation policies for transformative change: Combining insights from innovation systems and multi-level perspective in a comprehensive failures framework. Research Policy, 41 (6), 1037- 1047

Wu, C.Y., Mathews J. A. (2012). Knowledge flows in the solar photovoltaic industry: Insights from patenting by Taiwan, Korea, and China. Research Policy, 41 (3), 524-540

Wustenhagen, R., Bilharz, M. 2006. Green energy market development in Germany: effective public policy and emerging customer demand. Energy Policy, 34, 1681-1696 